\title{
Alternative Cell Death Mechanisms Determine Epidermal Resistance in Incompatible Barley-Ustilago Interactions
}

\author{
Alexander Hof, ${ }^{1}$ Bernd Zechmann, ${ }^{2}$ Daniela Schwammbach, ${ }^{1}$ Ralph Hückelhoven, ${ }^{3}$ and \\ Gunther Doehlemann ${ }^{1}$ \\ ${ }^{1}$ Max Planck Institute for Terrestrial Microbiology, Department of Organismic Interactions, Karl-von-Frisch Str. 10, D-35043 \\ Marburg, Germany; ${ }^{2}$ Institute of Plant Sciences, Karl-Franzens University of Graz, 8010 Graz, Austria; ${ }^{3} \mathrm{Chair}$ of \\ Phytopathology, Center of Life and Food Science Weihenstephan, Technische Universität München, 85350 Freising- \\ Weihenstephan, Germany
}

Submitted 23 October 2013. Accepted 27 November 2013.

\begin{abstract}
Programmed cell death is a key feature of epidermal plant immunity, which is particularly effective against biotrophic microbes that depend on living host tissue. The covered smut fungus Ustilago hordei establishes a compatible biotrophic interaction with its host plant barley. The maize smut $U$. maydis triggers a nonhost response in barley, which results in epidermal cell death. Similarly, Ustilago mutants being deleted for pep1, a gene encoding a secreted effector, are blocked upon host penetration. We studied the epidermal responses of barley to incompatible Ustilago strains. Molecular and cellular analyses were used to test the impact of Bax inhibitor-1 (BI-1), a suppressor of programmed cell death, on the barley nonhost resistance to $U$. maydis as well as Ustilago $\Delta$ pep1 mutants. Overexpression of BI-1 resulted in partial break of barley nonhost resistance to $U$. maydis. By contrast, the epidermal cell death response triggered by pep1 deletion mutants was not impaired by BI-1. Hypersensitive-response-like cell death caused by $\boldsymbol{U}$. maydis wild-type infection showed features of necrotic cell death, while $\Delta p e p 1$ mutant-induced host responses involved hallmarks of autophagy. Therefore, we propose that the mechanisms of epidermal cell death in response to different types of incompatible pathogens depend on spatial and temporal appearance of cell-death-triggering stimuli.
\end{abstract}

Biotrophic plant pathogens depend on an effective suppression of host immune responses to establish a compatible interaction. This particularly implies the avoidance of host cell death reactions, which typically result from the recognition of avirulence factors through specific resistance (R) proteins (Jones and Dangl 2006). Such cell death reactions are part of the hypersensitive response (HR), which is associated with a strong burst of reactive oxygen species (ROS) and shares similarities with apoptotic cell death processes (Greenberg and Yao 2004; Heath 2000; Lord and Gunawardena 2012). In addition,

Corresponding author: G. Doehlemann; Telephone: +49-6421-178-602; Fax: +49-6421-178-609; E-mail: doehlemann@mpi-marburg.mpg.de

* The $\boldsymbol{e}$-Xtra logo stands for "electronic extra" and indicates that four supplementary figures and three supplementary tables are published online.

(C) 2014 The American Phytopathological Society unspecific defenses triggered by the perception of pathogen associated molecular patterns (PAMPs) can also induce plant cell death when not being suppressed by the pathogen (Thomma et al. 2011). Thus, the induction of programmed cell death (PCD) is a crucial component of plant immunity. In mammals, a clear distinction can be made between apoptotic (type I) and autophagic (type II) cell death, determined by the interplay of the anti-apoptotic factor Bcl-2 and the autophagic induced Beclin-1 (Maiuri et al. 2007). In plants, however, this differentiation is vague because PCD can display hallmarks of both processes (van Doorn 2011; van Doorn et al. 2011). Although still under controversial debate, it is largely accepted that apoptotic cell death is not conserved in plants. PCD in plants mainly differentiates between necrotic cell death, which is characterized by an early rupture of the plasma membrane, protoplast shrinkage, and swelling of mitochondria; and vascular cell death, which includes accumulation of autophagosomes and other lytic vacuoles (van Doorn et al. 2011). A mixed situation can be found in HR-associated cell death, which usually shows characteristics of necrotic cell death but also involves hallmarks of vacuolar cell death such as tonoplast rupture and the requirement of vacuolar processing enzyme (VPE) activity (van Doorn et al. 2011).

The role of autophagy in pathogen-triggered plant cell death is also controversially discussed. There is evidence for autophagy to promote cell survival and restrict spread of cell death in HRs in Nicotiana benthamiana (Liu et al. 2005). However, a pro-death role of autophagy was observed in Arabidopsis thaliana during the HR cell death in an $R$-gene-triggered immune response (Hofius et al. 2009, 2011).

A well-studied factor in PCD is Bax inhibitor-1 (BI-1). BI-1 has been identified as an endoplasmic reticulum (ER)-resident protein that represents an ancient suppressor of PCD, being functionally and structurally conserved within eukaryotes (Hückelhoven 2004; Watanabe and Lam 2009). A connection of BI-1 and autophagy has recently been described in mice, where BI-1 was found to act as a stress integrator that modulates autophagy levels (Castillo et al. 2011). In line with this, Sano and associates (2012) recently showed that BI-1-deficient mice show reduced autophagy levels.

In maize and barley, it was found that the PCD-inhibiting function of BI-1 is required for full susceptibility to the biotrophic fungal pathogens Ustilago maydis and Blumeria graminis f. sp. hordei, respectively (Eichmann et al. 2010; van der Linde et al. 2011). Complementary to this, overexpression of 
BI-1 in barley leads to an increased susceptibility to the nonadapted biotroph B. graminis f. sp. tritici but causes partial resistance to the necrotroph Fusarium graminearum (Babaeizad et al. 2009; Eichmann et al. 2004).

It is an accepted model that development of the plant immune system and microbial virulence factors are the product of an evolutionary arms race that decides on disease resistance of susceptibility (Jones and Dangl 2006). Key players in this contention are effector proteins, which are produced by pathogens to interfere with the plant immune system. In this regard, one can distinguish "core effectors" that suppress PAMP-triggered immunity (PTI) and, therefore, are basal factors of microbial virulence; and more specialized effectors that interfere with specific defense signaling processes and, thereby, also inhibit the suppression of R-protein-mediated resistance (effector-triggered immunity [ETI]) (Doehlemann and Hemetsberger 2013; Jones and Dangl 2006). A core effector with an essential function for fungal virulence is Pep1. This protein was identified in $U$. maydis, which establishes a biotrophic interaction with its host plant maize and develops intracellular hyphae upon direct penetration of the host epidermis (Doehlemann et al. 2009). Deletion mutants for pepl are blocked in penetration of the first attacked epidermal cell and elicit various plant defenses, particularly the accumulation of ROS and, finally, cell death. Recently, it was found that Pep1 inhibits apoplastic peroxidases and, thereby, suppresses the apoplastic, PAMP-triggered oxidative burst response which identifies Pep1 as a basal suppressor of plant immunity (Hemetsberger et al. 2012). Also, in the barley covered smut pathogen $U$. hordei, Pep1 is required for epidermal penetration (Doehlemann et al. 2009). Similar to $U$. maydis on maize, $U$. hordei establishes a biotrophic interaction with barley. However, whereas $U$. maydis forms plant tumors locally at infection sites, $U$. hordei colonizes the plant almost symptom free until seed are replaced by fungal spores in the inflorescences (Laurie et al. 2012). Both related pathogens are well adapted to their host plants, and $U$. maydis does not cause disease in barley.

In this study, we describe the cellular responses of barley to the compatible biotroph $U$. hordei in comparison with the nonhost responses to $U$. maydis as well as the $U$. hordei and $U$. maydis pepl deletion ( $\triangle$ pepl) mutants, respectively. The findings presented in this study suggest that, in different types of incompatible interactions, differential epidermal cell death responses are activated.

\section{RESULTS}

\section{Ustilago-triggered epidermal immune responses} in barley.

For a quantitative analysis of the infection process, compatible $U$. hordei wild-type strains were inoculated on leaves of barley seedlings ('Golden Promise') 10 days postsawing. In addition, three incompatible interactions were analyzed: $U$. maydis wild type as well as the $U$. hordei and $U$. maydis $\Delta p e p 1$ mutants. The $\Delta$ pepl mutants have previously been described to be defective in epidermal penetration, while inducing an epidermal cell death response (Doehlemann et al. 2009). To monitor pathogen differentiation, penetration efficiency, and viability of the infected host cells, a combination of stains for lifecell imaging was applied for confocal microscopy. Appressoria formation was quantified using Calcofluor staining of fungal filaments on the leaf surface. In addition, penetration efficiency was quantified at $30 \mathrm{~h}$ postinoculation (hpi) after treating the infected leaves with the dyes Calcofluor and fluorescein diacetate (FDA) to stain fungal structures on the leaf surface and, additionally, show the penetrated hypha within the epidermal cell by visualization of the invaginated plant cytoplasm (Fig. 1; Supplementary Fig. S1).

At 24 hpi, filaments of the $U$. hordei and $U$. maydis wild-type strains, as well as the $U$. hordei and $U$. maydis $\Delta p e p 1$ mutant
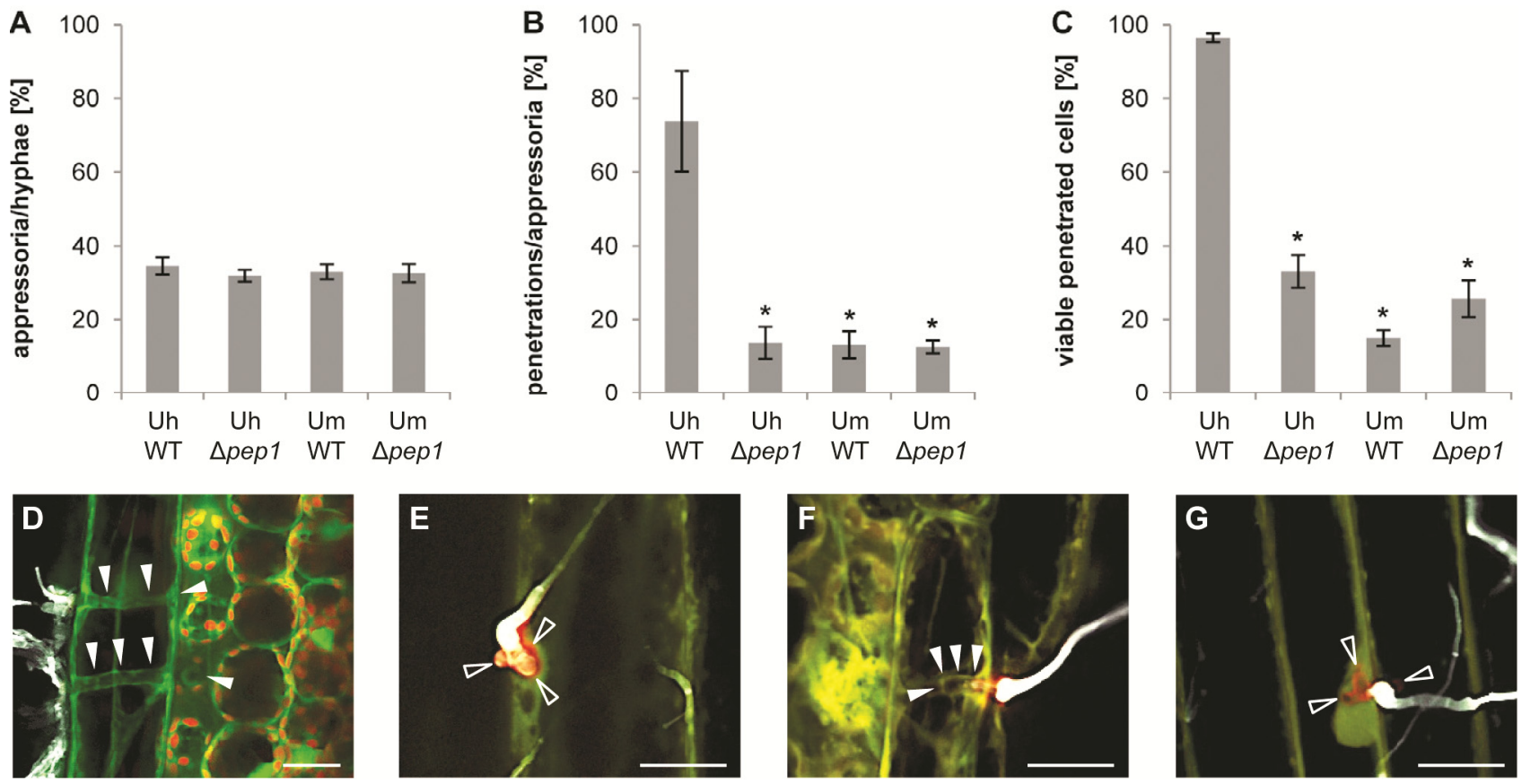

Fig. 1. Formation of infection structures and barley epidermal penetration by Ustilago maydis and the $U$. hordei wild type (WT) and $\Delta p e p 1$ mutant strains A, Quantification of appressoria formation $20 \mathrm{~h}$ postinoculation (hpi) on barley leaves. B, Quantification of penetration efficiency of filaments that formed appressoria, 30 hpi. C, Cell viability of penetrated epidermal cells, $48 \mathrm{hpi}$. D to G, Confocal images of representative epidermal penetration events of D, $U$. hordei wild type; $\mathbf{E}, U$. hordei $\Delta p e p 1 ; \mathbf{F}, U$. maydis wild type; and $\mathbf{G}, U$. maydis $\Delta p e p 1$. Images were taken 30 hpi. Green $=$ fluorescein diacetate stain, white $=$ Calcofluor-stained fungal hyphae, red $=$ FM4-64-stain. Bars $=20 \mu \mathrm{m}$. Open arrowheads $=$ penetration attempts of $\Delta p e p 1$ strains. White arrowheads $=$ intracellular hypha of $U$. hordei and U. maydis WT strains. All experiments were performed in at least three biological replicates. Error bars indicate standard deviation. Asterisks indicate significance $P<0.0005$, calculated by an unpaired $t$ test. 
strains, had formed appressoria to similar rates on the barley leaves (Fig. 1A). In case of the $U$. hordei wild type, $74 \% \pm$ $14 \%$ of appressoria led to a successful epidermal penetration and, in $97 \% \pm 1 \%$, the invaded host cells were viable $48 \mathrm{~h}$ after infection (Fig. 1B and C). This reflects the compatibility of $U$. hordei to its host plant barley (Fig. 1B to D). In contrast, only $13 \% \pm 4 \%$ of $U$. maydis wild-type appressoria successfully penetrated an epidermal cell. Similar rates were observed for both $U$. hordei and U. maydis $\Delta$ pepl mutants (Fig. 1B). However, cytological analysis showed that the $\Delta$ pepl hyphae of both $U$. hordei and $U$. maydis were blocked immediately upon penetration, showed multiple penetration attempts, and did not show subsequent intracellular growth (Fig. 1E and G). This observation was in line with previous reports on the U. maydis $\Delta$ peplmaize interaction (Doehlemann et al. 2009; Hemetsberger et al. 2012). Similarly, U. maydis wild-type hyphae were blocked within the first penetrated epidermis cell (Fig. 1F). However, multiple penetration attempts, as found for $\Delta$ pepl hyphae, were not observed and intracellular growth of $U$. maydis hyphae was blocked within the cell lumen rather than immediately at the cell wall (Fig. 1E and F). Nevertheless, penetration efficiency of the $U$. maydis wild type was not higher than that of $\Delta p e p 1$ mutants, indicating an effective epidermal resistance to both wild-type and mutant strains. Penetration attempts by either the U. maydis wild type or the U. hordei and U. maydis $\Delta p e p 1$ mutants caused cell death in most cases (Fig. 1C). Only $15 \% \pm$ $2 \%$ of the $U$. maydis-infected cells were viable after $48 \mathrm{~h}$, and $26 \% \pm 5 \%(33 \% \pm 5 \%)$ of the U. maydis (U. hordei) $\Delta p e p 1-$ mutant-infected cells were viable (Fig. 1C). In summary, these observations show that both $U$. maydis as well as the $\Delta p e p 1$ mutants of $U$. hordei and $U$. maydis are blocked in epidermal penetration and fail to establish a biotrophic interaction with barley.

\section{Overexpression of barley BI-1 rescues epidermal resistance to the $U$. maydis wild type but not $\Delta$ pep1 mutants.}

In a previous study, we concluded that disruption of pepl leads to a "non-host-like" situation (Doehlemann et al. 2009). Indeed, the inability of $\Delta p e p 1$ mutants to suppress the peroxidase-driven oxidative burst (Hemetsberger et al. 2012) results in an epidermal immune response of barley that shares similarities with the nonhost interaction to $U$. maydis (Fig. 1). Because the observed epidermal defense response suggested an involvement of PCD, the role of PCD was studied by using barley lines that constitutively overexpress green fluorescent protein (GFP)-tagged BI-1 (Babaeizad et al. 2009). Surprisingly, overexpression of BI-1 did not have any detectable impact on $\Delta$ pepl mutant infections. In three independent BI-1overexpressing barley lines, the penetration efficiency of both the U. maydis $\Delta$ pepl and U. hordei $\Delta p e p 1$ mutants was not

Fig. 2. Influence of Bax inhibitor-1 (BI-1) on epidermal resistance of barley to Ustilago hordei and U. maydis wild type (WT) and respective $\Delta p e p 1$ mutants. A, Quantification of penetration efficiency, $30 \mathrm{~h}$ postinoculation (hpi). E14L, E4L3, and E15L7 are independent transgenic lines overexpressing BI-1 (Babaeizad et al. 2009). B, Visualization and quantification of $\mathrm{H}_{2} \mathrm{O}_{2}$ accumulation 48 hpi using diaminobenzedene (DAB) stain. Blue = Calcofluor-stained fungal hyphae. Brown $=$ DAB precipitation. Arrowheads $=U$. maydis penetration attempt. $\mathbf{C}$, Visualization and quantification of barley cell death, 48 hpi. Green $=U$. maydis hyphae stained by WGAAlexa Fluor 488. Blue = Epidermal cell stained by trypan blue. Arrowheads $=U$. maydis penetration attempt. Bars $=20 \mu \mathrm{m}$. BI-1 oe $=\mathrm{BI}-1$ overexpressing line E14L1 (see A); WT = wild-type barley control. All experiments were performed in at least three biological replicates. Error bars indicate standard deviation. Asterisks indicate significance $P<0.005$, calculated by an unpaired $t$ test. altered (Fig. 2A) (i.e., overexpression of BI-1 did not affect the epidermal resistance of barley to these fungal strains). By contrast, the $U$. maydis wild type showed significantly increased penetration efficiencies on the BI-1 plants. At $30 \mathrm{~h}$ after infection, approximately $34 \% \pm 6 \%$ of $U$. maydis wild-type appressoria resulted in a successful penetration, compared with only $13 \% \pm 4 \%$ in barley control plants (Fig. 2A). This enhanced penetration efficiency was also associated with a significant suppression of $\mathrm{H}_{2} \mathrm{O}_{2}$ formation and cell death in the penetrated
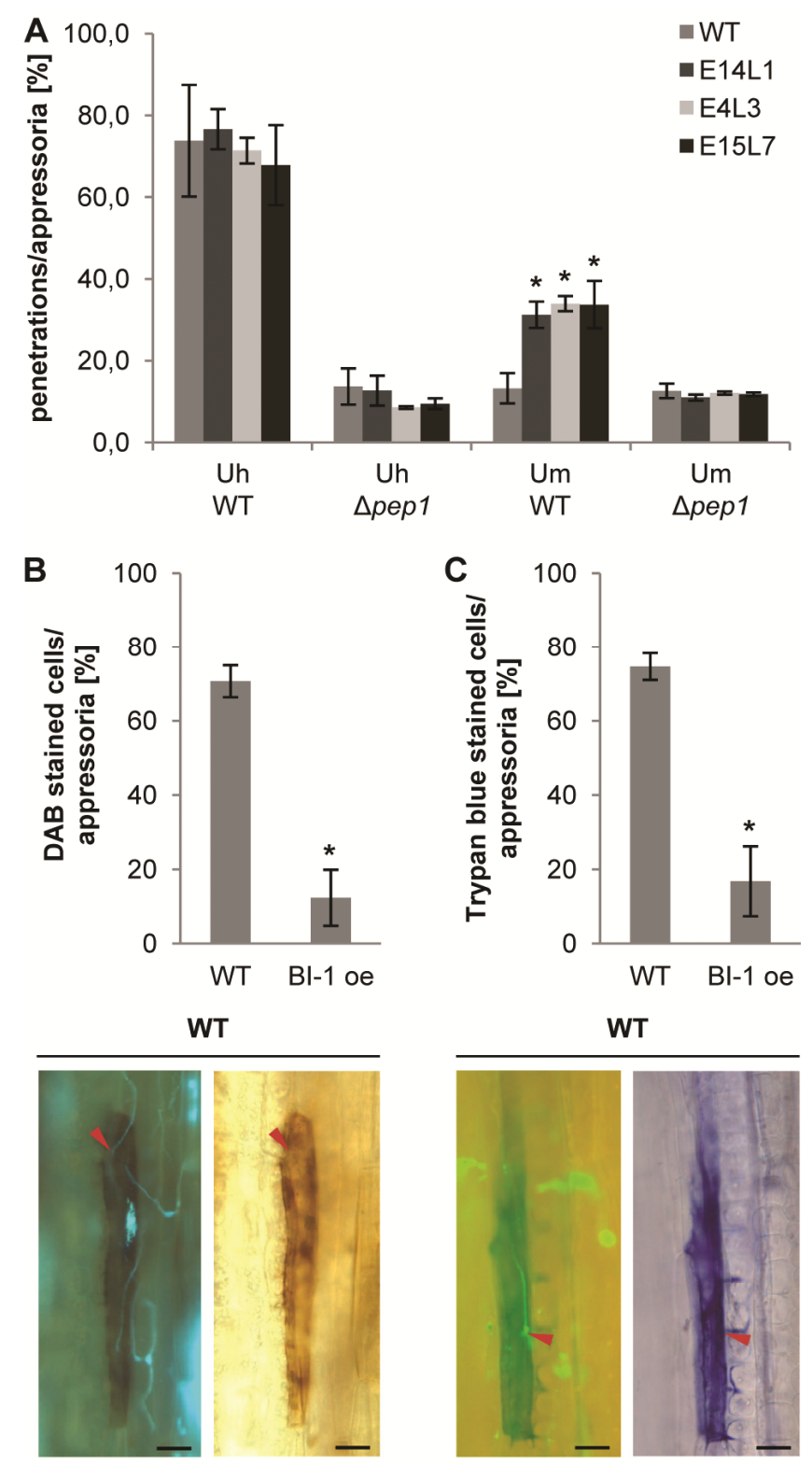

BI-1 oe

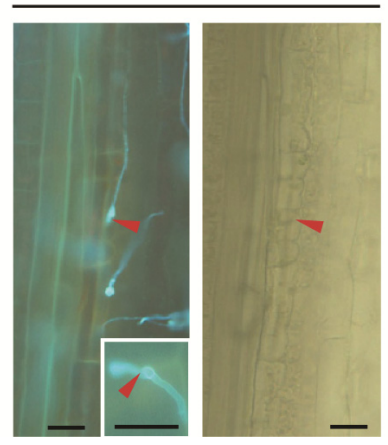

BI-1 oe

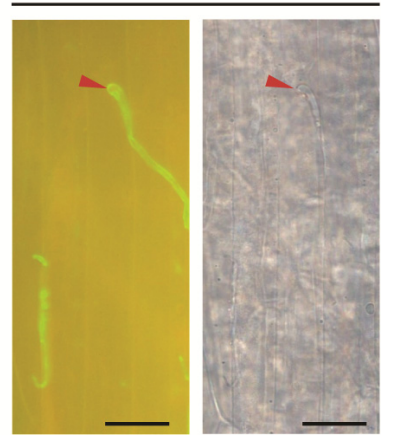


epidermis cells (Fig. 2B and C). In wild-type barley plants 48 h after infection, approximately $70 \%$ of all $U$. maydis-attacked cells showed an accumulation of $\mathrm{H}_{2} \mathrm{O}_{2}$, indicated by diaminobenzedene (DAB) precipitation. At the same time, approximately $75 \%$ of epidermal cells underwent cell death, indicated by trypan blue staining (Fig. $2 \mathrm{~B}$ and $\mathrm{C}$ ). In the BI-1-overexpressing barley plants, only $12 \% \pm 8 \%$ cells showing DAB precipitation and $17 \% \pm 9 \%$ were stained by trypan blue, respectively (Fig. 2B and C). In line with this, BI-1-overexpressing plants contained intracellular $U$. maydis wild-type cells that showed hyphal branching, which was not the case in wildtype plants (Supplementary Fig. S2). Taken together, the overexpression of BI-1 significantly suppresses epidermal nonhost resistance to $U$. maydis, whereas the responses induced by the spepl mutants appeared to be not affected by BI-1. Based on these observations, we hypothesized that the cell death response triggered by $\Delta p e p l$ infections differs from the reaction which is triggered by the $U$. maydis wild type.

\section{Barley responses}

to $U$. maydis wild-type and $\Delta p e p 1$ infections.

Barley leaves infected by the $U$. maydis wild type showed different macroscopic symptoms when compared with $\Delta$ pepl mutant infections. The U. maydis wild type caused large clusters of chlorotic cells and necrotic lesions in the infected leave areas, whereas $\Delta p e p 1$ mutant strains induced only locally restricted chlorosis and no spreading necrotic lesions 6 days after inoculation (Supplementary Fig. S3). In line with this, $U$. maydis-infected plants showed a significant retardation in growth, whereas leaf length of $\Delta p e p 1$-mutant-infected plants was comparable with that of $U$. horde $i$ wild-type infections.
To get a more detailed insight into the different barley responses to the $U$. maydis wild type and the $\Delta$ pepl mutants, transcriptional responses of the defense- or HR-associated marker genes pathogenesis-related $(P R)-1$ and $P R-10$ and the class-III WRKY-22 transcription factor were tested. Quantitative real-time polymerase chain reaction (qRT-PCR) showed almost no induction of these genes in the compatible $U$. hordei infection at 24 and $48 \mathrm{hpi}$ (Fig. 3A to C). By contrast, $U$. maydis infection caused a strong transcriptional activation of all three genes. At $24 \mathrm{hpi}, P R-1$ (35-fold), $P R-10$ (64-fold), and $W R K Y$-22 (39-fold) showed a significant induction. This induction was even more pronounced at $48 \mathrm{hpi}$, when all marker genes showed a $>100$-fold induction compared with mock controls (Fig. 3A to C; Supplementary Table S3). In contrast to this, in $\Delta$ pepl infections, only a moderate induction was observed for the $P R$ genes and $W R K Y-22$ at $24 \mathrm{hpi}$ whereas, at $48 \mathrm{hpi}$, expression levels of the three marker genes were not altered or even lower compared with $24 \mathrm{hpi}$ (Fig. 3A to C).

Another typical plant response to nonadapted pathogens is the oxidative burst. To test this reaction in the different Ustilago spp. interactions, $\mathrm{H}_{2} \mathrm{O}_{2}$ concentrations in apoplastic fluids of barley leaves were quantified at the infection sites using a xylenol-orange-based readout (Bindschedler et al. 2001, 2006). At $12 \mathrm{hpi}$, when filaments are growing on the leaf surface but not yet started epidermal penetration, no significant elevation of $\mathrm{H}_{2} \mathrm{O}_{2}$ was detectable in any of the Ustilago infections (Fig. 3D). At the 24-h time point, which represents the penetration phase, both the $U$. maydis $\Delta p e p 1$ and $U$. hordei $\Delta$ pepl strains caused a strong $\mathrm{H}_{2} \mathrm{O}_{2}$ accumulation. In contrast, $U$. maydis wild-type-infected samples did not show elevated $\mathrm{H}_{2} \mathrm{O}_{2}$ levels at this stage (Fig. 3D). This situation, however, changed at 48
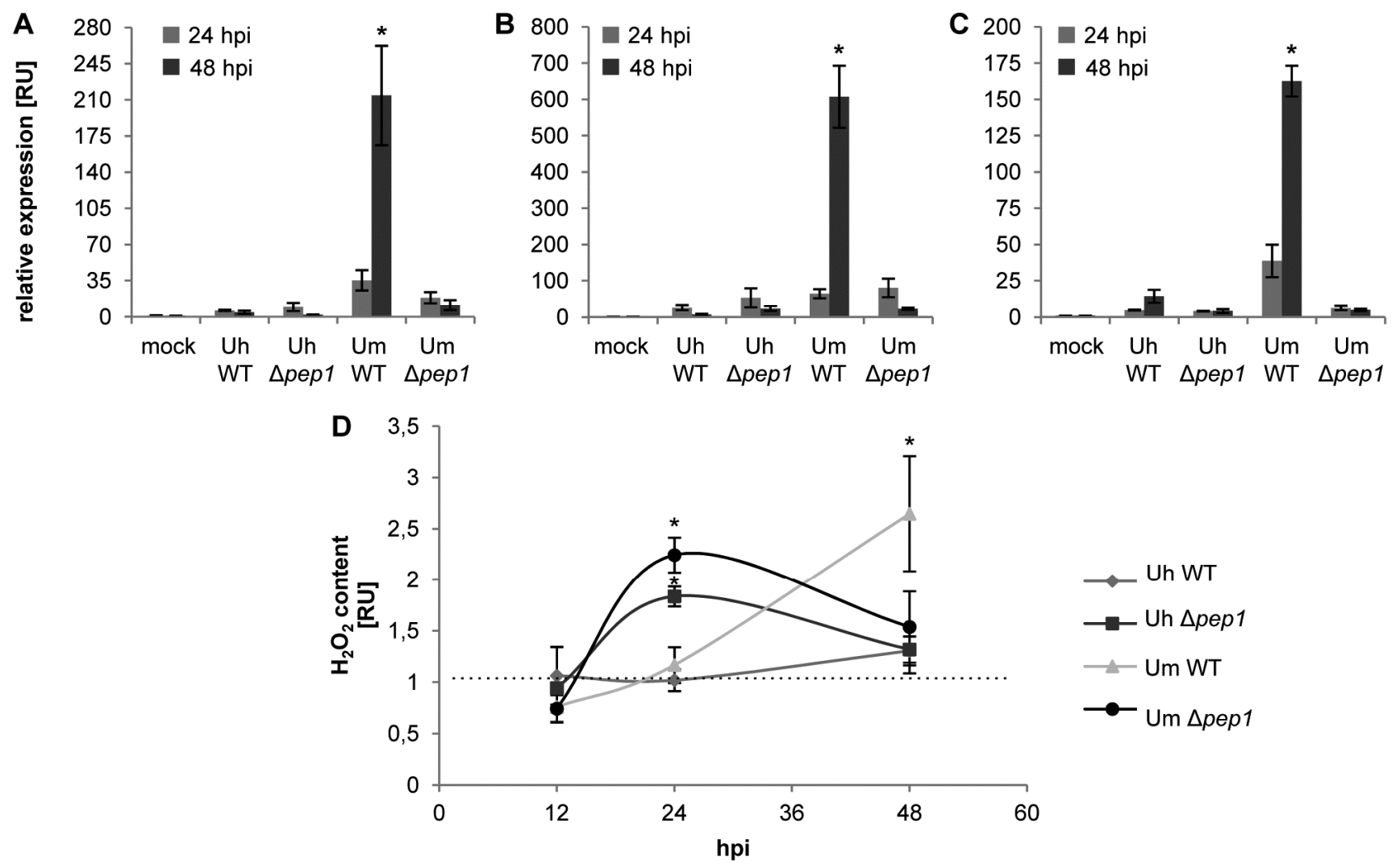

Fig. 3. Barley defense responses to Ustilago maydis and $U$. hordei wild type (WT) and respective $\Delta$ pep1 mutant strains. A-C, Quantitative real-time polymerase chain reaction of barley defense genes in response to $U$. hordei and $U$. maydis wild type (WT) and $\Delta p e p 1$ mutant infections. A, PR-1; B, PR-10; and C, WRKY-22 relative to mock-treated samples. D, Quantification of $\mathrm{H}_{2} \mathrm{O}_{2}$ in apoplastic fluid of Ustilago-infected barley leaves in relation to mock-treated leaves (dashed line). All experiments were performed in at least three biological replicates. Error bars indicate standard error of the mean. Asterisks indicate significance $P<0.005$, calculated by an unpaired $t$ test. 
h. At that point, the $U$. maydis wild-type-infected leaves displayed a strong oxidative burst, which exceeded the $\mathrm{H}_{2} \mathrm{O}_{2}$ contents of $\Delta$ pepl samples at 24 hpi. The $\mathrm{H}_{2} \mathrm{O}_{2}$ levels in $\Delta p e p 1$ infections were comparable with those of $U$. hordei wild-type infections at this time point, indicating that the triggered oxidative burst response had already declined at 48 hpi (Fig. 3D).

\section{Epidermal cell death responses}

\section{to $U$. maydis wild-type and $\Delta p e p 1$ mutant strains.}

BI-1 has previously been shown to be involved in suppression of plant PCD and HR-associated cell death (Eichmann et al. 2006; Kawai-Yamada et al. 2001; Wang et al. 2012). The observed partial breakdown of nonhost resistance of BI-1overexpressing barley to $U$. maydis suggests an involvement of necrotic or HR-like cell death in this interaction. Therefore, we used fluorescence-based enzymatic assays to monitor caspaselike activites as well as VPE activity in barley leaves. DEVDase activity (caspase-3-like) during plant cell death was reported in various cases (del Pozo and Lam 1998; Fernández et al. 2012; Han et al. 2012; Rodríguez-Serrano et al. 2012; Zhang et al. 2009). VPE and caspase-1-like activities were previously shown to be required for hypersensitive cell death in plants in response to viral infection and mycotoxin treatment (Hatsugai et al. 2004; Kuroyanagi et al. 2005; van Doorn et al. 2011). We used N-Acetyl-Asp-Glu-Val-Asp-4-methyl-coumaryl-7-amide (Ac-DEVD-MCA) as a selective substrate for caspase-3-like activity, to be incubated with crude leaf extracts of infected plants. At 12 hpi (prepenetration), no differences in substrate cleavage were detected in all tested Ustilago infections compared with mock treated samples. At $30 \mathrm{hpi}$, (postpenetration), the infection by the $U$. maydis wild type resulted in a significant induction of caspase-3-specific substrate cleavage (Fig. 4). In contrast, neither $U$. hordei wild-type nor the $\Delta$ pepl strains led to a significant induction of DEVDase activity (Fig. 4). Treating the samples with the specific caspase-3 inhibitor N-Acetyl-Asp-Glu-Val-Asp-1-aldehyde (Ac-DEVD-CHO) reduced the activity in all samples to a similar background level, confirming specificity of the observed DEVDase activity (Fig. 4). Similarly as for DEVDase, we tested substrates AcYVAD-MCA for caspase-1-like activity and Ac-ESEN-MCA for VPE activity. These activities also were induced only by $U$. maydis wild-type infection but not by $\Delta p e p 1$ mutants. In both cases, a significant induction of activity was found at the postpenetration stage 30 hpi (Supplementary Fig. S4) although, for both caspase-1-like and VPE, the level of induction was weaker compared with DEVDase (Fig. 4).

The specific induction of caspase-like and VPE activites in $U$. maydis wild-type-infected leaves as well as the finding that $\Delta$ pepl infections are independent from BI-1 suggest the execution of different types of PCD. Because autophagy was reported to play an important role in innate immunity and PCD in plants, we hypothesized that this process could be involved in cell death reactions to $\Delta p e p 1$ infections. Therefore, we visualized the induction of autophagy upon Ustilago infections by staining infected leave areas with monodansylcadaverine (MDC). This basic, permeable dye has been shown to localize to acidic compartments and, therefore, stains autophagosomes (Contento et al. 2005; Kabbage et al. 2013). NaCl-induced plasmolysis was used as a positive control to trigger autophagy in barley epidermis cells. Although mock-treated cells did not show MDC-staining (Fig. 5A), plasmolytic epidermal cells that served as positive control showed MDC-stained particles (Fig. 5B). Next, the MDC stain was applied to Ustilago spp.infected leaves during epidermal penetration (30 hpi). Typically, neither $U$. hordei nor $U$. maydis wild-type-infected cells showed MDC-stained particles (Fig. 5C and D). Conversely, epidermal cells infected by the $U$. hordei and $U$. maydis $\Delta p e p 1$ mutants contained MDC-stained particles (Fig. 5E and F) and these structures were found motile in the infected cells (Fig. $5 \mathrm{G}$ to I). Moreover, induction of autophagy was exclusively observed in infected cells and did not spread to surrounding tissue (Fig. 5J). Quantification revealed MDC-stained particles in $5 \% \pm 2 \%$ of $U$. hordei wild-type-infected cells. A similar picture was observed after $U$. maydis wild-type infection, where $8 \% \pm 3 \%$ of infected cells were positive for MDC (Fig. $5 \mathrm{~K})$. For both the $U$. hordei and $U$. maydis $\Delta p e p 1$ mutants, MDC signals were detected in more than $80 \%$ of attacked barley cells (Fig. 5K). Because specificity of MDC staining is questioned in recent literature, Lysotracker red was used as an alternative assay to probe autophagy-related acidification of vacuolar or lysosomal structures. In line with the observations made for MDC, Lysotracker-red-stained structures accumulated in $\Delta$ pepl-infected cells, whereas both $U$. hordei and $U$. maydis wild-type infections showed only background signal (Fig. 6). The co-staining of Lysotracker red with FDA also showed loss of protoplast viability in $U$. maydis wild-type infection already during the penetration phase at $30 \mathrm{hpi}$ (Fig. 6B).

In addition to life-cell imaging, the cellular responses to Ustilago infections were analyzed by transmission electron microscopy (TEM), which is considered to be the prime analytical method to diagnose plant cell death (van Doorn et al. 2011). In the TEM experiments, cerium chloride $\left(\mathrm{CeCl}_{3}\right)$ was used to visualize $\mathrm{H}_{2} \mathrm{O}_{2}$. U. hordei wild-type hyphae were found to grow inside barley cells without any obvious accumulation of $\mathrm{H}_{2} \mathrm{O}_{2}$ and no ultrastructural changes of the host cell were evident (Fig. 7). By contrast, accumulation of $\mathrm{H}_{2} \mathrm{O}_{2}$ could be visualized in $U$. maydis wild-type-infected barley cells. In particular, $\mathrm{H}_{2} \mathrm{O}_{2}$ was found to accumulate in the mitochondria but was also detected in plant cytoplasm and cell walls (Fig. 7). A quantification of subcellular $\mathrm{H}_{2} \mathrm{O}_{2}$ accumulation in response to fungal infection showed increased $\mathrm{H}_{2} \mathrm{O}_{2}$ levels in all incompatible interactions compared with the $U$. hordei wild type. However, whereas, in U. maydis $\Delta p e p 1$ and $U$. hordei $\Delta p e p 1$, $\mathrm{H}_{2} \mathrm{O}_{2}$ was only induced in plant and fungal cell walls, $U$. maydis wild-type infection caused a strong accumulation of $\mathrm{H}_{2} \mathrm{O}_{2}$ in plant cytoplasm and mitochondria (Fig. 8).

Furthermore, U. maydis-penetrated cells showed tonoplast rupture, blebbing of the plasma membrane, and swollen mitochondria with dilated cristae (Fig. 7). In barley cells penetrated

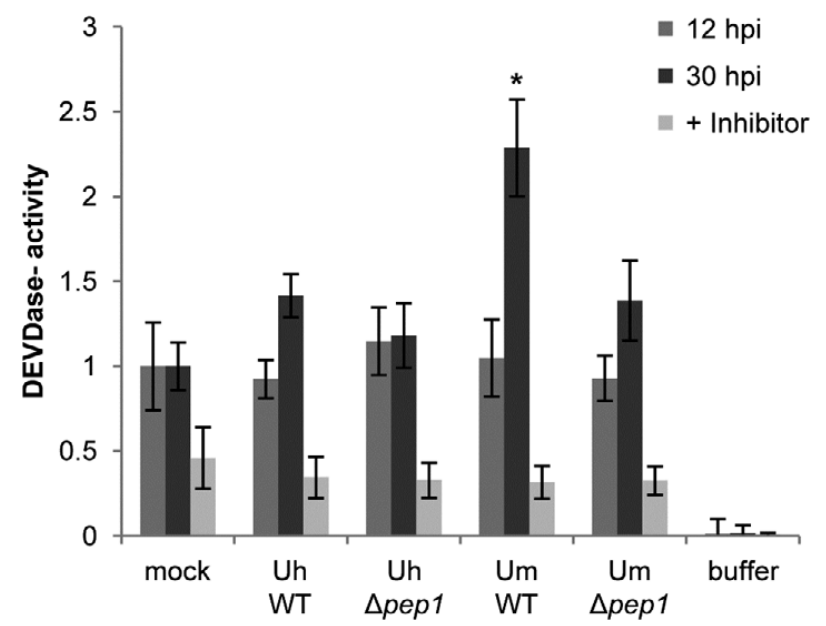

Fig. 4. Caspase-3-like activity in Ustilago-infected barley leaves 12 and 30 $\mathrm{h}$ postinoculation (hpi). Caspase-3-like (DEVDase) activity was measured using the specific fluorigenic substrate Ac-DEVD-MCA relative to mocktreated samples. As inhibitor of caspase-3-specific activity, Ac-DEVD$\mathrm{CHO}$ was used. All experiments were performed in at least three biological replicates. Error bars indicate standard error of the mean. Asterisks indicate significance $P<0.05$, calculated by an unpaired $t$ test. 
by either $U$. maydis $\Delta p e p l$ or $U$. hordei $\Delta p e p l$ hyphae, $\mathrm{H}_{2} \mathrm{O}_{2}$ accumulation was restricted to cell walls and was not observed in cytoplasm and mitochondria (Fig. 7). Strikingly, spep 1infected cells clearly showed autophagosomes in both cytoplasm and vacuole, which was true for both $U$. maydis $\Delta$ pep1 and U. hordei $\Delta$ pepl (Fig. 7).
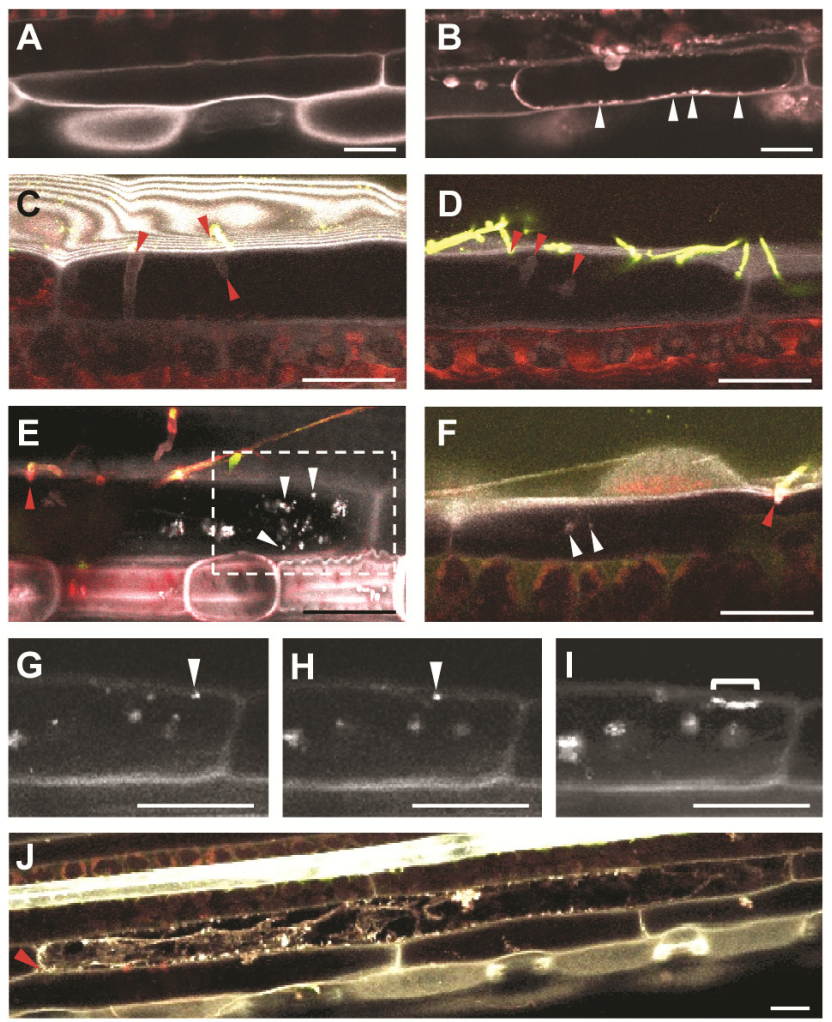

$\mathbf{K}$

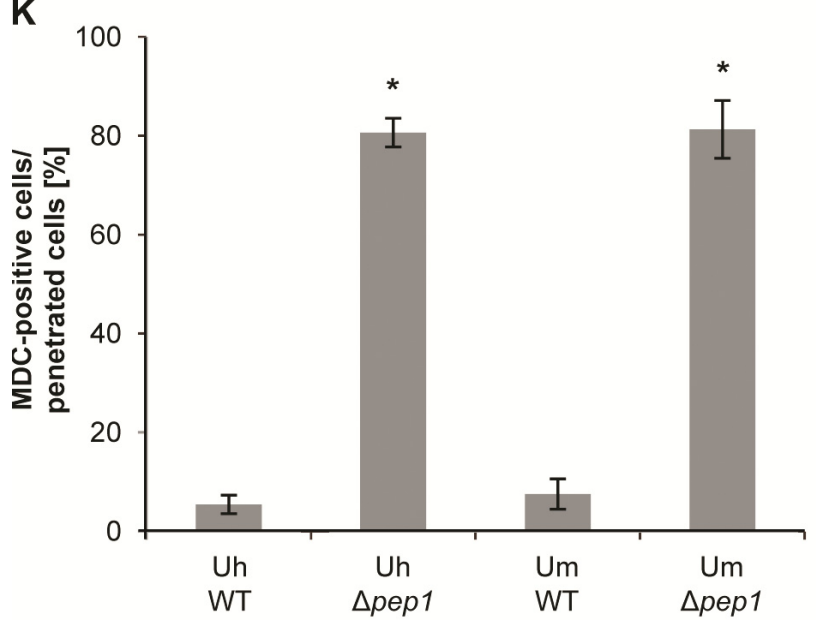

Fig. 5. Life-cell imaging of autophagosomes in barley epidermis cells in response to Ustilago infection using monodansylcadaverine (MDC) stain. A, Mock-treated barley epidermal cell. B, Barley epidermal cell showing NaCl-triggered plasmolysis. $\mathbf{C}$ to $\mathbf{F}$, Barley epidermis cells infected by $\mathbf{C}$, Ustilago hordei wild type (WT); D, U. maydis WT; E, U. hordei $\Delta$ pep1; and $\mathbf{F}, U$. maydis $\Delta$ pep1. $\mathbf{G}$ and $\mathbf{H}$, Images showing inset marked in $\mathrm{E}$ with moving MDC-stained particles (arrowhead). I, Overlay of an image series $(\mathrm{G}$ and $\mathrm{H})$ following movement of an MDC-stained particle (bracket). A to $\mathbf{G}$, Images were taken at $30 \mathrm{~h}$ postinoculation (hpi). J, U. hordei spepl infected epidermal cell (arrow) and neighboring cell without autophagy staining at $48 \mathrm{hpi}$. Bars $=20 \mu \mathrm{m} \mathrm{K}$, Quantification of autophagy in infected epidermal cells 30 hpi. White arrowheads = MDC-stained particles. Red arrowheads = infectious hyphae. All experiments were performed in at least three biological replicates. Error bars indicate standard deviation. Asterisks indicate significance $P<0.0005$, calculated by an unpaired $t$ test.
Together, these data provide evidence for distinct cellular responses of barley to infection by $U$. maydis wild-type- and $\Delta$ pep1-mutant-infected cells. Although nonhost reactions to $U$. maydis trigger BI-1-controlled HR-like cell death, responses to $\Delta$ pepl infections show typical hallmarks of autophagy, are independent from BI-1, and also lack further features of necrotic death such as mitochondrial disintegration and induction of caspase-like activity. Therefore, autophagy in response to $\Delta$ pepl infections appears to be an alternative mechanism to the HR that is triggered by the $U$. maydis wild type, which shows several hallmarks of necrotic cell death.

\section{DISCUSSION}

In this study, we analyzed the epidermal defense responses of barley during incompatible interactions with the biotrophic smut fungi $U$. maydis and $U$. hordei. Prior to host penetration, the maize pathogen $U$. maydis forms infection structures at the same level as the adapted barley pathogen $U$. hordei, indicating that surface cues of barley leaves fully trigger the patho-
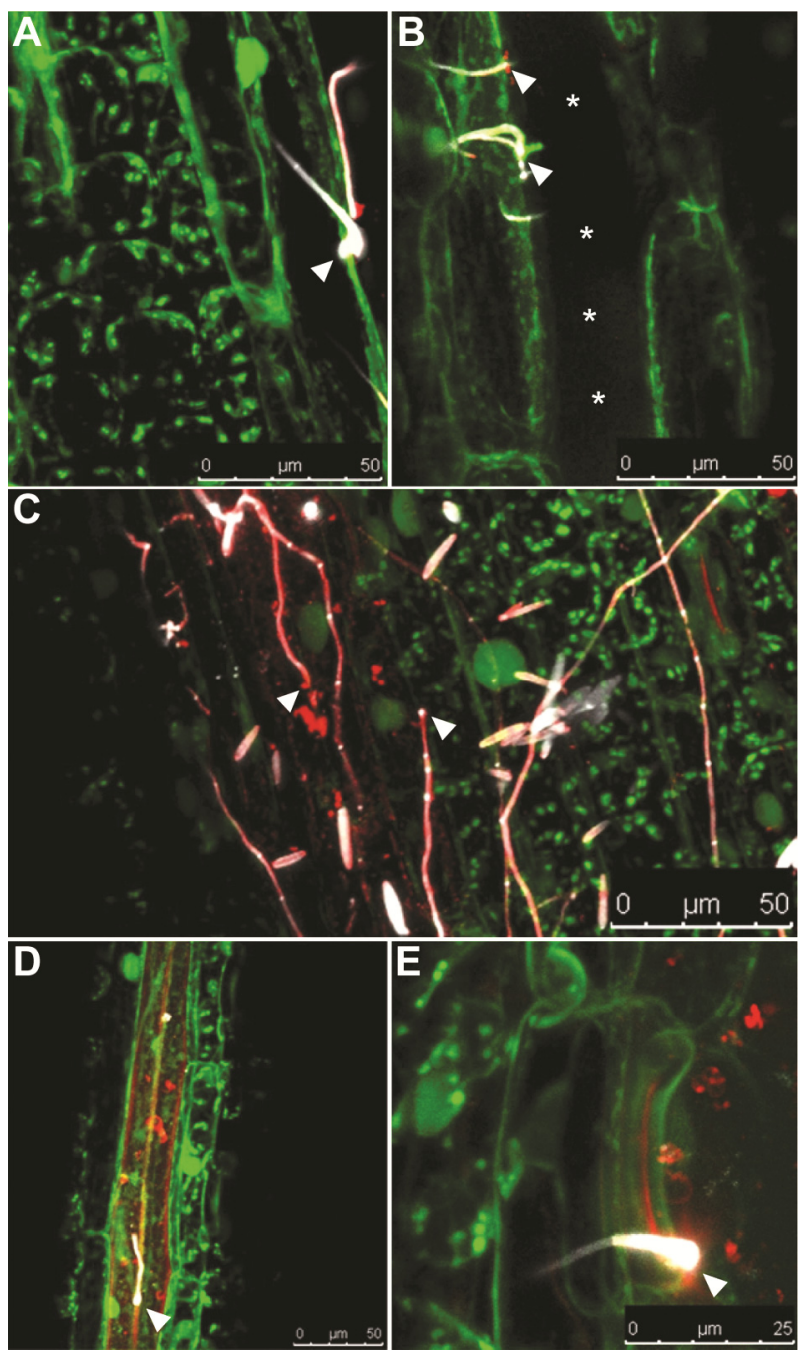

Fig. 6. Lysotracker-red staining of barley epidermis cells in response to Ustilago infections $30 \mathrm{~h}$ postinoculation. A, Ustilago hordei wild-type infection and $\mathbf{B}, U$. maydis wild-type infection. Asterisks mark the non-fluorescein diacetate (FDA)-stained cell that underwent cell death. $\mathbf{C}$, Infection with $U$. hordei $\Delta p e p 1$. D and $\mathbf{E}$, Infection with U. maydis $\Delta p e p 1$. White $=$ Calcofluor-stained fungal hyphae and green $=$ FDA-stained plant cytoplasm and plant nuclei. In mesophyll cells, green autofluorescence gets visible (A, C, and E). Red = Lysotracker-red-stained lysosomes or vacuoles. White arrowheads $=$ Ustilago penetration attempts. 
genic differentiation of $U$. maydis. The same observation was made for both $U$. hordei and $U$. maydis mutants that carry deletions for the pepl gene. However, the $U$. maydis wild type as well as the $\Delta$ pepl mutants were blocked upon epidermal penetration and, in most cases, the infected cells underwent cell death, although $U$. maydis wild-type-triggered cell death responses were more severe compared with $\Delta p e p l$ infections. The $U$. maydis wild type caused large necrotic areas and stunted leaf growth whereas responses to $\Delta p e p 1$ mutants remained restricted to infection sites. Interestingly, the deletion of pepl in $U$. maydis led to a phenotype indistinguishable to that of the $U$. hordei $\Delta p e p 1$ mutants. This suggests that the
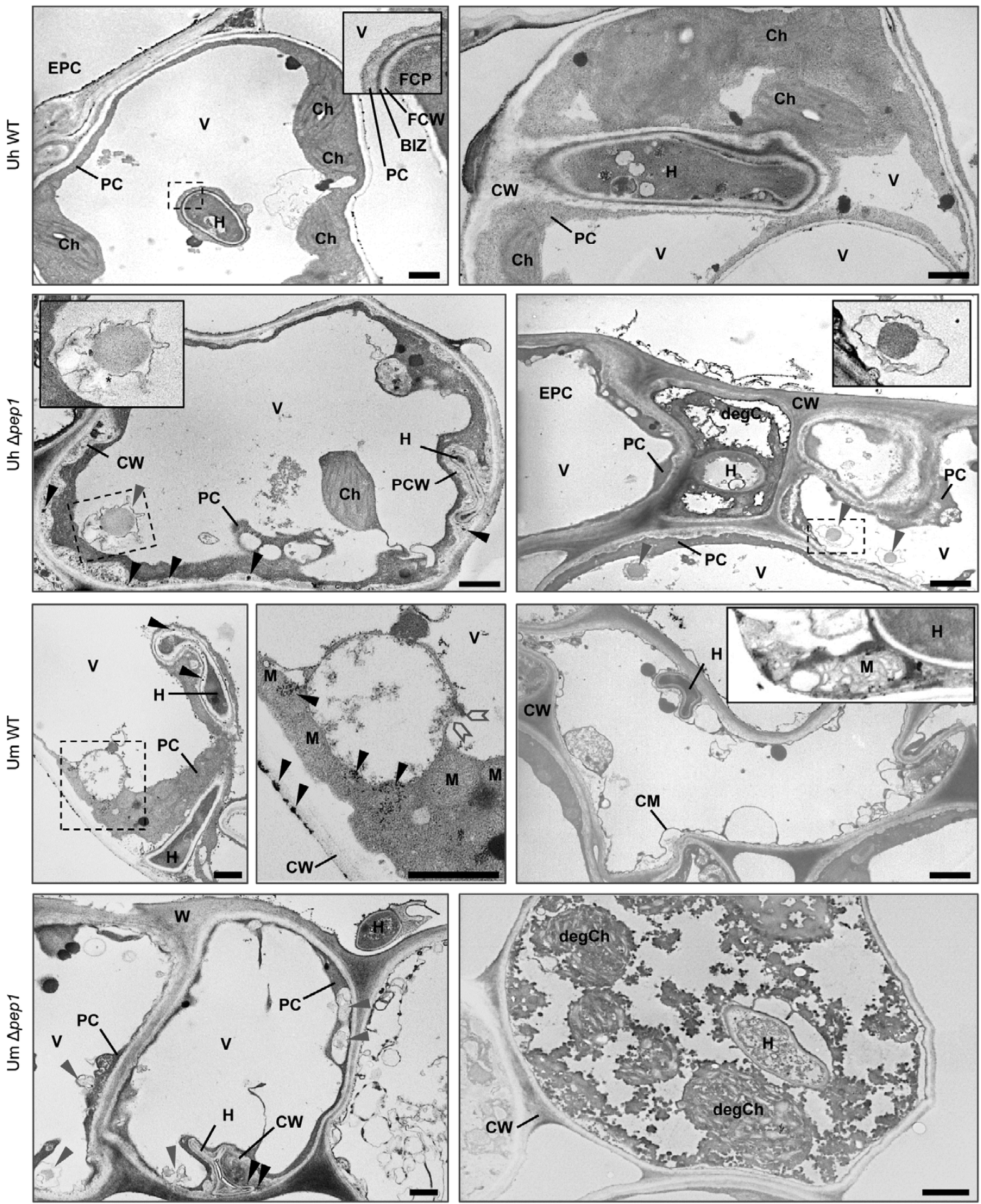

Fig. 7. Transmission electron microscopy of Ustilago infected barley cells with visualization of $\mathrm{H}_{2} \mathrm{O}_{2}$ using cerium chloride $\left(\mathrm{CeCl}_{3}\right)$. $\mathrm{H}_{2} \mathrm{O}_{2}$ accumulation is visualized by $\mathrm{CeCl}_{3}$ staining (black arrowheads) in cell walls (CW), the cytosol (CCP), and mitochondria (M) in Ustilago maydis wild-type (WT)-infected cells. Tonoplast rupture (open chevrons) could also be observed in penetrated cells. Inset: swollen mitochondria with dilated cristae. Bars $=1 \mu \mathrm{m}$. $U$. hordei WT penetrated cells show a dense cytosol with chloroplasts $(\mathrm{Ch})$ and vacuoles $(\mathrm{V})$ with intact tonoplast. $\mathrm{CeCl}_{3}$ staining was absent or very low. Inset: enlarged biotrophic interface. Bars $=1 \mu \mathrm{m}$. Cells penetrated by $\Delta$ pepl mutant strains show autophagosomes (gray arrowheads) and $\mathrm{H}_{2} \mathrm{O}_{2}$ accumulation (black arrowheads) in CW. Insets: enlarged autophagosomes. Bars $=1 \mu \mathrm{m} . \mathrm{EPC}=$ epidermal cell, $\mathrm{PC}=$ plant cytosol, $\mathrm{BIZ}=$ biotrophic interaction zone, $\mathrm{FCW}=$ fungal cell wall, $\mathrm{FCP}=$ fungal cytoplasm, $\mathrm{H}=$ hypha, $\operatorname{deg} \mathrm{C}=$ degraded cytosol, $\mathrm{CM}=$ cytoplasm membrane, and degCh $=$ degraded chloroplast. 
more dramatic cell death response toward the $U$. maydis wild type actually depends on the presence of Pep1. Activity of this effector is required for an activation of PCD that can be suppressed by BI-1 (i.e., in the absence of Pep1, a BI-1 independent cell death pathway is triggered in barley epidermal cells).

The Pep1 effector is a secreted peroxidase-inhibitor, which is required for epidermal penetration and the suppression of the PAMP-triggered oxidative burst (Hemetsberger et al. 2012). The $U$. maydis $\Delta$ pepl penetration defect was complemented by either scavenging extracellular ROS or silencing of the Pep1-targeted oxidative-burst maize peroxidase POX12 (Hemetsberger et al. 2012). Given the defense-suppressing function of Pep1, it may appear contradictory that nonhost responses to $U$. maydis $\Delta p e p 1$ mutants are less severe compared with wild-type infections. An explanation comes from the celldeath mechanisms that are activated in the different interactions. Although the HR-like cell death in the nonhost resistance of barley to the $U$. maydis wild type was suppressed by BI-1, its expression did not have any effect on the $\Delta$ pepl mutant infections. First, this indicates that nonhost resistance to $U$. maydis involves necrotic cell death, which is in line with several previous findings (Eichmann et al. 2004, 2006). Second, this strongly suggests that cell death induced by the $\Delta$ pepl mutants does not implicate necrotic cell death. The same conclusion can be drawn from the quantification of VPE and caspase-like activities. Although caspases themselves are not present in plants, metacaspases have been identified, which show homologies to the caspases of apoptosis (Uren et al. 2000) and are able to induce PCD in yeast (Watanabe and Lam 2005). Additionally, accumulating evidence supports the existence of caspase-like activity in plants and its functional involvement in various types of plant PCD (Bonneau et al. 2008; He et al. 2008; Lam 2005; Qiang et al. 2012; Reape et al. 2008; Sanmartín et al. 2005; Woltering 2004; Woltering et al. 2002; Zhang et al. 2009). U. maydis wild-type infection significantly induced caspase-3-like (and, to a weaker extent, caspase-1-like and VPE) activity at 30 hpi whereas, in $U$. maydis $\Delta$ pepl mutant infections, these activities were comparable with $U$. hordei infections.

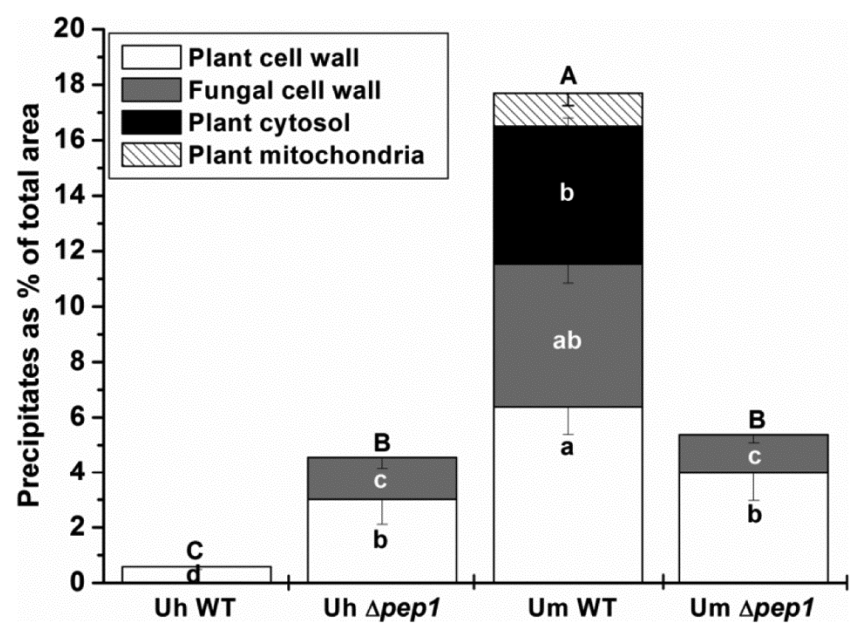

Fig. 8. Compartment-specific accumulation of $\mathrm{H}_{2} \mathrm{O}_{2}$. The subcellular accumulation of $\mathrm{H}_{2} \mathrm{O}_{2}$ was quantified on transmission electron micrographs by determining the area of cerium chloride $\left(\mathrm{CeCl}_{3}\right)$ staining in the different cell compartments. Graphs show means with standard errors which document the percentage of areas covered by $\mathrm{CeCl}_{3}$ precipitates in the individual cell compartments; $n>40$ for the individual cell compartments. Different lowercase letters indicate significant differences $(P<0.05)$ between the individual cell compartments whereas uppercase letters indicate significant differences between the total amounts of $\mathrm{CeCl}_{3}$ staining for all analyzed cell compartments taken together. Data were analyzed with the Kruskal-Wallis test followed by post-hoc comparison according to Conover (1999).
Instead of hallmarks for necrotic cell death, $\Delta$ pepl mutant infections were associated with an induction of autophagy. Strong accumulation of MDC-positive vesicles was observed in $\Delta$ pepl-infected cells but not in $U$. maydis wild-type infections. Similarly, Lysotracker-red stain was specifically found in $\Delta$ pepl-infected epidermal cells. However, because MDC is not strictly selective for autophagosomes and might also stain other acidic compartments such as early endosomes (Klionsky et al. 2008), confirmation for the induction of autophagy came from the TEM data. Autophagosomes got visible in $\triangle$ pepl mutant-infected barley cells but were observed in neither $U$. hordeinor $U$. maydis wild-type-challenged cells. Together, this provides substantial evidence for a specific induction of autophagy in spepl infections. However, a significant transcriptional induction of autophagy-related atg genes (Bassham et al. 2006) was not observed by using qRT-PCR (not shown). A likely explanation for this negative result is the small number of cells that actually perform autophagy in response to an Ustilago infection. Only the epidermal cells that were infected by spepl mutant hyphae executed autophagy, whereas the surrounding tissue did not show any detectable responses. This situation very likely leads to a dilution of transcriptional changes in whole-leaf RNA samples. In addition, the restricted cell death reaction in $\Delta p e p 1$-infected leaves also explains the weaker macroscopic symptoms compared with $U$. maydis wild-type infections, where spreading cell death and retarded growth were observed. At the same time, this phenotype supports the suggested role of autophagy in limiting the spread of pathogen-induced PCD (Liu et al. 2005; Yoshimoto et al. 2009) because the expanding cell death in the U. maydis wildtype-infected leaves is restricted in $\Delta p e p l$ infections.

At this point, one should state that the presented data provide support for an activation of autophagy during epidermal resistance to $\Delta p e p 1$ mutant strains. What cannot be doubtlessly concluded thus far is whether these autophagic processes actually cause the observed cell death. In order to elucidate a functional role of the autophagy pathway in cell death, Shen and Codogno (2011) proposed that cell death by autophagy could occur independent of necrotic cell death, which is true in the situation described in this study. In addition, autophagic cell death should also be associated with an increase of autophagic flux and, consequently, suppression of autophagy is able to prevent cell death (Shen and Codogno 2011). In other systems, this was tested by inhibitors such as 3-methyladenine. This approach, however, is not possible in the Ustilago system, because infections occur to primordia within the leaf whirl, which cannot be infiltrated by inhibitor solutions prior to fungal infection. Therefore, future experiments will require stable knockdown barley lines for autophagy components, such as Atg8, to directly confirm the functional connection of autophagy and cell death in $\Delta$ pepl infections.

Lacking evidence of autophagy induction during $U$. maydis wild-type infections does not implement an autophagy independent from HR. In A. thaliana, a role of autophagy during the immunity-associated hypersensitive cell death was shown recently (Kwon et al. 2013). In light of the present study, one could summarize that, depending on the trigger, an HR either could be executed primarily through necrotic cell death, because it shows up in $U$. maydis wild-type infections, or it could be characterized by autophagy instead, as in $\Delta p e p 1$ infections. For the necrotrophic fungal pathogen Sclerotinia sclerotiorum, a recent report discovered an important role of the interplay between autophagy and necrotic cell death for successful infection (Kabbage et al. 2013). S. sclerotiorum induces necrotic cell death to kill host tissue but it also requires the ROS-scavenging reductant oxalic acid as a virulence factor to successfully establish infection (Williams et al. 2011). Kabbage and 
associates (2013) concluded that oxalic acid functions as suppressor of autophagy, because this needs to be suppressed by $S$. sclerotiorum to establish infection; whereas, in the onset of the interaction, this necrotrophic fungus promotes necrotic cell death to cause disease. This observation, although being made in a quite unrelated system (dicot host versus monocot host and necrotrophic pathogen versus biotrophic pathogen) shows remarkable parallels to the situation we found in the present study. First, these complementary independent findings strengthen the hypothesis that necrotic cell death and vacuolar cell death, including autophagy, are the two major pathways in pathogen responses. Second, these two cell-death mechanisms seem to act alternatively (i.e., depending on the trigger, either autophagy or necrotic cell death is activated). This view may also bring together the partially contradictory reports considering autophagy as either "pro-survival" or "pro-death" (Hofius et al. 2009, 2011; Liu et al. 2005). With regard to its impact on necrotic cell death, autophagy can be considered as a pro-survival mechanism because, when activated, necrotic responses are attenuated. However, during PTI, autophagy functions as an efficient, local response to restrict epidermal penetration and avoid spreading cell death. This is what we observed in $\Delta$ pepl infections.

The decision as to whether autophagy is triggered likely depends on i) the compartment and ii) the time point when ROS accumulation occurs. The spepl-infected cells show $\mathrm{H}_{2} \mathrm{O}_{2}$ stain mostly in the cell wall, while $U$. maydis wild-typeinfected cells show strongly increased $\mathrm{H}_{2} \mathrm{O}_{2}$ levels in the cytoplasm and the mitochondria, which appeared swollen and showed dilated cristae. The latter is similar to the HR-type cell death triggered in barley ETI to B. graminis f. sp. hordei (An et al. 2006). In $\Delta p e p 1$ infections, the early, PAMP-triggered apoplastic oxidative burst is not suppressed because the peroxidase-inhibiting Pep1 effector is lacking. This leads to a massive accumulation of extracellular $\mathrm{H}_{2} \mathrm{O}_{2}$ (Hemetsberger et al. 2012) which may act as a trigger of autophagy. This is in line with the elevated $\mathrm{H}_{2} \mathrm{O}_{2}$ levels in $\Delta$ pepl infections at $24 \mathrm{hpi}$, which represents the penetration phase of Ustilago spp. At 48 h after $\Delta$ pepl infection, $\mathrm{H}_{2} \mathrm{O}_{2}$ levels were decreased almost to control levels and barley cells around infection sites were unaffected, indicating that no spreading cell death occurred. In contrast, in $U$. maydis wild-type infections, an oxidative burst was observed only after epidermal penetration (48 hpi). Here, the early PAMP-triggered burst is suppressed by Pep1, which is functionally conserved among $U$. maydis and $U$. hordei (Doehlemann et al. 2009). However, after penetration of the epidermal cell wall, predominantly necrotic cell death is induced, coinciding with a massive induction of $P R-1, P R-10$, and $W R K Y-22$ and an oxidative burst response that exceeds the $\mathrm{H}_{2} \mathrm{O}_{2}$ levels induced upon $\Delta p e p 1$-infections. This nonhost response is likely triggered by $U$. maydis effectors being not adapted to barley and, therefore, recognized in barley to cause ETI. Remarkably, the U. maydis $\Delta$ pepl mutants do not cause this response. It behaves indistinguishably from $U$. hordei spepl and induces an early oxidative burst and autophagy but no indications for necrotic cell death. This substantiates the specific induction of the HR-like cell death in the presence of Pep1, where PAMP-induced responses are suppressed. Generally, a block of plant pathogens that fails to suppress the initial PAMP-triggered, extracellular oxidative burst is associated with epidermal autophagy, which remains restricted to the challenged cells and, therefore, causes only limited damage to the plant. This is also reflected by the minor macroscopic symptoms of barley plants treated with $\Delta p e p 1$ mutants compared with $U$. maydis wild-type infections. A nonadapted pathogen that deploys core effectors such as Pep1 can suppress basal defense and thereby trigger an HR-like ETI response that shows hallmarks of BI-1-dependent, necrotic cell death. Compared with PTI-triggered cell death, this response is more costly to the plants, which is indicated by macroscopically visible necrosis and stunted growth.

\section{MATERIALS AND METHODS}

\section{Strains and growth conditions.}

All Ustilago strains used in this study (Supplementary Table $\mathrm{S} 1$ ) were grown in $0.4 \%$ yeast extract, $0.4 \%$ peptone, and $2 \%$ sucrose, incubating the $U$. hordei strains at $22^{\circ} \mathrm{C}$ and $U$. maydis strains at $28^{\circ} \mathrm{C}$, with shaking at 200 rounds $\min ^{-1}$. For plant infections, cultures were grown to an optical density at $600 \mathrm{~nm}\left(\mathrm{OD}_{600}\right)$ of 0.7 to 1.0. Cells were centrifuged at 1,000 $\times g$ for $10 \mathrm{~min}$, resuspended in $0.1 \%$ Tween 20 to an $\mathrm{OD}_{600}$ of 3 , and used for infection of 10-day-old barley seedlings. Plant infections were performed comparable with the established maize infection method as described earlier (Molina and Kahmann 2007). For experiments, barley plants (Hordeum vulgare L. Golden Promise and Golden Promise expressing GFPHvBI-1 under control of promoter CaMV35S) (Babaeizad et al. 2009) were grown in phytochambers at $22^{\circ} \mathrm{C}$ during the light period $(30,000 \mathrm{lux}, 16 \mathrm{~h})$ and at $18^{\circ} \mathrm{C}$ during the dark period $(8 \mathrm{~h})$, with $60 \%$ relative humidity.

\section{Enzymatic caspase-like activity assay.}

For the preparation of total leaf extracts, 2- to 4-cm sections of the infected leaves were excised $1 \mathrm{~cm}$ below the injection site at the respective time points, frozen in liquid nitrogen, and ground to a powder with a cold mortar and pestle. The powder was collected and resuspended in two volumes of cold extraction buffer $(10 \mathrm{mM}$ sodium phosphate buffer [pH 7.3], 150 $\mathrm{mM} \mathrm{NaCl}, 1 \mathrm{mM}$ EDTA, $2 \mathrm{mM}$ dithiothreitol, $20 \mu \mathrm{M}$ E-64, and Aprotinin at $10 \mathrm{mg} / \mathrm{ml}$ ), followed by three rounds of centrifugation for $10 \mathrm{~min}$ at $16,000 \times g$ and $4^{\circ} \mathrm{C}$ to remove cell debris. Supernatants were then filtered through a $35-\mu \mathrm{m}$ nylon filter (BD Biosciences, Heidelberg, Germany) and samples were maintained at $4^{\circ} \mathrm{C}$. Protein content was measured according to Bradford (1976) and samples were adjusted to a protein concentration of $1 \mathrm{mg} / \mathrm{ml}$, immediately proceeding with proteolytic activity measurements.

Proteolytic activity was measured using the fluorimetric mammalian caspase-3 substrate Ac-DEVD-MCA (dissolved in dimethyl sulfoxide [DMSO]) (Peptanova, Sandhausen, Germany), which leads to release of fluorescence at $460 \mathrm{~nm}$ when cleaved by caspase-3 activity (Enari et al. 1996; Nicholson et al. 1995; Thornberry et al. 1997; Zimmerman et al. 1976). Then, $10 \mu \mathrm{l}$ of $100 \mu \mathrm{M}$ substrate was incubated with $80 \mu \mathrm{l}$ of leaf extract $(1 \mathrm{mg} / \mathrm{ml})$ and added to a final reaction volume of $100 \mu \mathrm{l}$ with $10 \mu \mathrm{l}$ of DMSO. To analyze the effect of a specific caspase- 3 inhibitor on substrate cleavage, $80 \mu \mathrm{l}$ of soluble extract was incubated with $10 \mu \mathrm{l}$ of the reversible inhibitor peptide Ac-DEVD-CHO (dissolved in DMSO) for $10 \mathrm{~min}$ at room temperature, prior to substrate addition. Measurements of caspase-1-like activity and VPE were performed following the same protocol used for caspase-3-like activity. For caspase-1like activity, substrate Ac-YVAD-MCA was used and, for VPE activity-measurements, we applied substrate Ac-ESEN-MCA. All substrates were supplied by Peptanova. Fluorescence was monitored every 10 min over a time course of $1 \mathrm{~h}$ using a fluorometer (Safire; Tecan, Crailsheim, Germany) and slope values were calculated. Background measurements were taken in the respective buffers and subtracted from sample values.

\section{Determination of ROS in apoplastic fluid.}

For the preparation of apoplastic fluid, 2- to 4-cm sections of the infected leaves were excised $1 \mathrm{~cm}$ below the injection 
site at the respective time points, followed by evacuation under water in a vacuum chamber for $3 \times 15 \mathrm{~min}$ at $100 \mathrm{mbar}$. The evacuated leaf sections were then stacked into packs of 10 to 20 and squeezed into the barrel of a 5-ml syringe so that the cut edges of the leaves faced the ends of the barrel. The barrel was then put into a $15-\mathrm{ml}$ falcon tube with the needle hub facing downward and spun for $20 \mathrm{~min}$ at $2,500 \times \mathrm{g}$ and $4{ }^{\circ} \mathrm{C}$. Afterward, the extracted apoplastic fluid was collected from the falcon tube and immediately used for the colorimetric visualization of ROS.

$\mathrm{H}_{2} \mathrm{O}_{2}$ production was quantified with a xylenol-orangebased readout according to Bindschedler and associates (2001, 2006) by incubating $10 \mu \mathrm{l}$ of apoplastic fluid with $90 \mu \mathrm{l}$ of xylenol orange solution. Absorption measurements of the assay solution were undertaken in a Tecan Safire plate reader (Infinite M 200 Pro; Tecan) every 5 min over a time course of $1 \mathrm{~h}$, and slope values were calculated. Background measurements were taken in the respective buffers and subtracted from sample values.

\section{RNA preparation, cDNA synthesis, and qRT-PCR.}

For expression analyses of HR-associated marker genes, 2to $4-\mathrm{cm}$ sections of the infected leaves were excised $1 \mathrm{~cm}$ below the injection site at the respective time points, frozen in liquid nitrogen, and ground to a powder with a cold mortar and pestle. The powder was collected and total RNA was extracted with TRIzol (Invitrogen, Karlsruhe, Germany) and purified using an RNeasy kit (Qiagen, Hilden, Germany), as described by the manufacturer. After extraction, the first-strand cDNA synthesis kit (Fermentas, St. Leon-Rot, Germany) was used to reverse transcribe $1 \mathrm{mg}$ of total RNA with oligo(dT) primers. The qRT-PCR analysis was performed using an iCycler (BioRad, Munich, Germany) in combination with the iQ SYBR Green Supermix (Bio-Rad). Primers for quantification of barley gene transcription levels are shown in Supplementary Table S2. Barley glyceraldehyde dehydrogenase (gapdh) was used as reference gene for normalization. Cycling conditions were as follows: $2 \mathrm{~min}$ at $95^{\circ} \mathrm{C}$, followed by 45 cycles of $30 \mathrm{~s}$ at $95^{\circ} \mathrm{C}$, $30 \mathrm{~s}$ at $61^{\circ} \mathrm{C}$, and $30 \mathrm{~s}$ at $72^{\circ} \mathrm{C}$. After each PCR, the threshold cycle above background was calculated using Bio-Rad iCycler software. Gene expression levels were then calculated relative to gapdh expression levels. Relative quantification of gene expression was carried out using a relative expression software tool (REST; Qiagen), applying an improved $\Delta \Delta$ analysis (Pfaffl et al. 2002).

\section{Staining procedures and microscopy.}

Autophagic vesicles were stained with MDC (Sigma-Aldrich, Deisenhofen, Germany) by incubating corresponding leaf sections with $100 \mu \mathrm{M}$ MDC final concentration in $1 \times$ phosphatebuffered saline (PBS) (137 mM NaCl, $2.7 \mathrm{mM} \mathrm{KCl}$, and 12 $\mathrm{mM}$ phosphate buffer, $\mathrm{pH}$ 7.4). Lysotracker red (Life Technologies, Darmstadt, Germany) for visualization of acidified vesicles was applied at a final concentration of $0.5 \mu \mathrm{M}$ in $1 \times$ PBS. Fungal hyphae were stained with WGA-AF 488 (Molecular Probes, Karlsruhe, Germany) by incubation in WGA-AF 488 at $10 \mu \mathrm{g} / \mathrm{ml}$ and $0.02 \%$ Tween 20 in $1 \times$ PBS. Plant membranes were visualized using FM4-64 (Molecular Probes, Karlsruhe, Germany) $(0.5 \mu \mathrm{g} / \mathrm{ml}$ in $1 \times$ PBS $)$ or propidium-iodide (SigmaAldrich) $(1 \mu \mathrm{g} / \mathrm{ml}$ in $1 \times$ PBS $)$. FDA (Sigma-Aldrich) $(0.5 \mu \mathrm{g} / \mathrm{ml}$ in $1 \times$ PBS) was used to stain the cytoplasm of plant cells. For all staining methods, leaf sections were infiltrated with the corresponding staining solution in a vacuum chamber for $3 \times 15$ min at 100 mbar. Plasmolysis was induced by incubating the corresponding leaf sections in $1 \mathrm{M} \mathrm{NaCl}$ for $10 \mathrm{~min}$. Visualization of $\mathrm{H}_{2} \mathrm{O}_{2}$ by DAB was performed as previously described by Molina and Kahmann (2007). For the analysis of cell via- bility, infected barley leaves were stained with trypan blue according to a modified protocol (Keogh et al. 1980). Leaves were submerged in ethanolic lactophenol-trypan blue staining solution and heated to $99^{\circ} \mathrm{C}$ for $8 \mathrm{~min}$. Subsequently, the staining solution was replaced by a saturated chloral hydrate solution $(2.5 \mathrm{~g} / \mathrm{ml})$ which was changed several times until the leaves were cleared. Leaves were stored in $50 \%$ (vol/vol) glycerol. To stain fungal material on leaf surfaces, excised leaf segments were incubated in Calcofluor Fluorescent Brightener 28 (Sigma-Aldrich) $(100 \mu \mathrm{g} / \mathrm{ml}$ in $0.2 \mathrm{M}$ Tris/ $\mathrm{HCl}, \mathrm{pH} 8.0)$ for $30 \mathrm{~s}$.

Confocal images were recorded on a TCS-SP5 confocal microscope (Leica, Bensheim, Germany) using an excitation at $488 \mathrm{~nm}$ and detection at 490 to $540 \mathrm{~nm}$ for WGA-AF 488 and FDA. Autofluorescence of cell wall material and Calcofluorwhite-stained fungal hyphae were excited at $405 \mathrm{~nm}$ and detected at 415 ti $460 \mathrm{~nm}$. For MDC-stained vesicles, excitation at $405 \mathrm{~nm}$ and detection at 490 to $520 \mathrm{~nm}$ was used. Lysotracker red was excited at $563 \mathrm{~nm}$ and detected at 570 to $600 \mathrm{~nm}$. FM4-64-stained plant membranes were visualized by excitation at $561 \mathrm{~nm}$ and detection at 570 to $640 \mathrm{~nm}$. Trypanblue-stained cells as well as DAB precipitates were recorded using a Leica DFC500 fluorescence camera that was installed at the TCS-SP5 confocal microscope.

Sample preparation for TEM was performed according to Hemetsberger and associates (2012). Small samples of leaves $\left(1 \mathrm{~mm}^{2}\right)$ were incubated with a $5-\mathrm{mM} \mathrm{CeCl}_{3}$ solution dissolved in $50 \mathrm{mM} 3$-(N-morpholino)propanesulfonic acid buffer for 1 $\mathrm{h}$ at $\mathrm{pH}$ 6.5. Subsequently, samples were fixed in a mixture of $2.5 \%$ paraformaldehyde and $2.5 \%$ glutardialdehyde dissolved in buffer at $\mathrm{pH} 7.2$ for $90 \mathrm{~min}$, rinsed in buffer $(4 \times 10 \mathrm{~min})$, and postfixed with $1 \%$ osmium tetroxide dissolved in buffer (pH 7.2). Dehydration was performed with increasing concentrations of acetone $(50,70,90$, and $100 \%)$ for $20 \mathrm{~min}$ for each step. Acetone was then exchanged with propylenoxide and samples were infiltrated with increasing concentrations of Agar 100 epoxy resin $(30,60$, and $100 \%)$. Samples were polymerized at $60^{\circ} \mathrm{C}$ for $48 \mathrm{~h}$. Ultrathin sections $(80 \mathrm{~nm})$ were cut with a Reichert Ultracut $S$ ultramicrotome and poststained for 5 min with a $2 \%$ lead citrate solution and for 15 min with $1 \%$ aqueous uranyl acetate before they were observed with a Philips CM10 TEM.

\section{ACKNOWLEDGMENTS}

Our work is supported by the Max Planck Society and the Deutsche Forschungsgemeinschaft. We thank D. Aßmann for excellent technical support and A. Harms for help with microscopic analysis of barley cell death in response to Ustilago maydis.

\section{LITERATURE CITED}

An, Q., Ehlers, K., Kogel, K.-H., van Bel, A. J. E., and Hückelhoven, R. 2006. Multivesicular compartments proliferate in susceptible and resistant MLA12-barley leaves in response to infection by the biotrophic powdery mildew fungus. New Phytol. 172:563-576.

Babaeizad, V., Imani, J., Kogel, K.-H., Eichmann, R., and Hückelhoven, R. 2009. Over-expression of the cell death regulator BAX inhibitor-1 in barley confers reduced or enhanced susceptibility to distinct fungal pathogens. Theor. Appl. Genet. 118:455-463.

Bassham, D. C., Laporte, M., Marty, F., Moriyasu, Y., Ohsumi, Y., Olsen, L. J., and Yoshimoto, K. 2006. Autophagy in development and stress responses of plants. Autophagy 2:2-11

Bindschedler, L. V., Minibayeva, F., Gardner, S. L., Gerrish, C., Davies, D. R., and Bolwell, G. P. 2001. Early signalling events in the apoplastic oxidative burst in suspension cultured French bean cells involve cAMP and $\mathrm{Ca}^{2+}$. New Phytol. 151:185-194.

Bindschedler, L. V., Dewdney, J., Blee, K. A., Stone, J. M., Asai, T., Plotnikov, J., Denoux, C., Hayes, T., Gerrish, C., Davies, D. R., Ausubel, F. M., and Bolwell, G. P. 2006. Peroxidase-dependent apoplastic oxida- 
tive burst in Arabidopsis required for pathogen resistance. Plant J. 47:851-863.

Bonneau, L., Ge, Y., Drury, G. E., and Gallois, P. 2008. What happened to plant caspases? J. Exp. Bot. 59:491-499.

Bradford, M. 1976. A rapid and sensitive method for the quantification of microgram quantities of protein utilizing the principles of protein-dye binding. Anal. Biochem. 72:248-254.

Castillo, K., Rojas-Rivera, D., Lisbona, F., Caballero, B., Nassif, M., Court, F. A., Schuck, S., Ibar, C., Walter, P., Sierralta, J., Glavic, A., and Hetz, C. 2011. BAX inhibitor-1 regulates autophagy by controlling the IRE1 $\alpha$ branch of the unfolded protein response. EMBO (Eur. Mol. Biol. Soc.) J. 30:4465-4478.

Conover, W.J. 1999. Practical Nonparametric Statistics, 3rd ed. John Wiley \& Sons, New York

Contento, A. L., Xiong, Y., and Bassham, D. C. 2005. Visualization of autophagy in Arabidopsis using the fluorescent dye monodansylcadaverine and a GFP-AtATG8e fusion protein. Plant J. 42:598-608.

Del Pozo, O., and Lam, E. 1998. Caspases and programmed cell death in the hypersensitive response of plants to pathogens. Curr. Biol. 8:11291132 .

Doehlemann, G., and Hemetsberger, C. 2013. Apoplastic immunity and its suppression by filamentous plant pathogens. New Phytol. 198:10011016.

Doehlemann, G., van der Linde, K., Aßmann, D., Schwammbach, D., Hof, A., Mohanty, A., Jackson, D., and Kahmann, R. 2009. Pep1, a secreted effector protein of Ustilago maydis is required for successful invasion of plant cells. PloS Pathog. 5:e1000290. Published online.

Eichmann, R., Holger, S., Kogel, K. H., and Hückelhoven, R. 2004. The barley apoptosis suppressor homologue Bax inhibitor-1 compromises nonhost penetration resistance of barley to the inappropriate pathogen Blumeria graminis f. sp. tritici. Mol. Plant-Microbe Interact. 17:484490

Eichmann, R., Biemelt, S., Schäfer, P., Scholz, U., Jansen, C., Felk, A., Schäfer, W., Langen, G., Sonnewald, U., Kogel, K. H., and Hückelhoven, R. 2006. Macroarray expression analysis of barley susceptibility and nonhost resistance to Blumeria graminis. J. Plant Physiol. 163:657-670.

Eichmann, R., Bischof, M., Weis, C., Shaw, J., Lacomme, C., Schweizer, P., Duchkov, D., Hensel, G., Kumlehn, J., and Hückelhoven, R. 2010. BAX INHIBITOR-1 is required for full susceptibility of barley to powdery mildew. Mol. Plant-Microbe Interact. 23:1217-1227.

Enari, M., Talanian, R. V., Wong, W. W., and Nagata, S. 1996. Sequential activation of ICE-like and CPP32-like proteases during Fas-mediated apoptosis. Nature 380:723-726.

Fernández, M. B., Daleo, G. R., and Guevara, M. G. 2012. DEVDase activity is induced in potato leaves during Phytophthora infestans infection. Plant Physiol. Biochem. 61:197-203.

Greenberg, J. T., and Yao, N. 2004. The role and regulation of programmed cell death in plant-pathogen interactions. Cell. Microbiol. 6:201-211.

Han, J. J., Lin, W., Oda, Y., Cui, K. M., Fukuda, H., and He, X. Q. 2012. The proteasome is responsible for caspase-3-like activity during xylem development. Plant J. 72:129-141.

Hatsugai, N., Kuroyanagi, M., Yamada, K., Meshi, T., Tsuda, S., Kondo, M., Nishimura, M., and Hara-Nishimura, I. 2004. A plant vacuolar protease, VPE, mediates virus-induced hypersensitive cell death. Science 305:855-858

He, R., Drury, G. E., Rotari, V. I., Gordon, A., Willer, M., Farzaneh, T., Woltering, E. J., and Gallois, P. 2008. Metacaspase- 8 modulates programmed cell death induced by ultraviolet light and $\mathrm{H}_{2} \mathrm{O}_{2}$ in Arabidopsis. J. Biol. Chem. 283:774-783.

Heath, M. C. 2000. Hypersensitive response-related cell death. Plant Mol. Biol. 44:321-334.

Hemetsberger, C., Herrberger, C., Zechmann, B., Hillmer, M., and Doehlemann, G. 2012. The Ustilago maydis effector Pep1 suppresses plant immunity by inhibition of host peroxidase activity. PloS Pathog. 8:e1002684. Published online.

Hofius, D., Munch, D., Bressendorff, S., Mundy, J., and Petersen, M. 2011. Role of autophagy in disease resistance and hypersensitive response-associated cell death. Cell Death Differ. 18:1257-1262.

Hofius, D., Schultz-Larsen, T., Joensen, J., Tsitsigiannis, D. I., Petersen, N. H., Mattsson, O., Jørgensen, L. B., Jones, J. D., Mundy, J., and Petersen, M. 2009. Autophagic components contribute to hypersensitive cell death in Arabidopsis. Cell 137:773-783.

Hückelhoven, R. 2004. BAX Inhibitor-1, an ancient cell death suppressor in animals and plants with prokaryotic relatives. Apoptosis 9:299-307.

Jones, J. D., and Dangl, J. L. 2006. The plant immune system. Nature 444:323-329.

Kabbage, M., Williams, B., and Dickman, M. B. 2013. Cell death control: The interplay of apoptosis and autophagy in the pathogenicity of Sclerotinia sclerotiorum. PloS Pathog. 9:e1003287. Published online.
Kawai-Yamada, M., Jin, U., Yoshinaga, K., Hirata, A., and Uchimiya, H. 2001. Mammalian Bax-induced plant cell death can be down-regulated by overexpression of Arabidopsis Bax inhibitor-1 (AtBI-1). Proc. Natl. Acad. Sci. U.S.A. 98:12295-12300.

Keogh, R. C., Deverall, B. J., and McLeod, S. 1980. Comparison of histological and physiological responses to Phakopsora pachyrhizi in resistant and susceptible soybean. Trans. Br. Mycol. Sci. 74:329-333.

Klionsky, D. J., Abeliovich, H., Agostinis, P., Agrawal, D. K., Aliev, G., Askew, D. S., Baba, M., Baehrecke, E. H., Bahr, B. A., Ballabio, A., Bamber, B. A., Bassham, D. C., Bergamini, E., Bi, X., BiardPiechaczyk, M., Blum, J. S., Bredesen, D. E., Brodsky, J. L., Brumell, J. H., Brunk, U. T., Bursch, W., Camougrand, N., Cebollero, E., Cecconi, F. Chen, Y., Chin, L. S., Choi, A., Chu, C. T., Chung, J., Clarke, P. G., Clark, R. S., Clarke, S. G., Clavé, C., Cleveland, J. L., Codogno, P., Colombo, M. I., Coto-Montes, A., Cregg, J. M., Cuervo, A. M., Debnath, J., Demarchi, F., Dennis, P. B., Dennis, P. A., Deretic, V., Devenish, R. J., Di Sano, F., Dice, J. F., Difiglia, M., Dinesh-Kumar, S., Distelhorst, C. W., Djavaheri-Mergny, M., Dorsey, F. C., Dröge, W., Dron, M., Dunn, W. A., Jr., Duszenko, M., Eissa, N. T., Elazar, Z., Esclatine, A., Eskelinen, E. L., Fésüs, L., Finley, K. D., Fuentes, J. M., Fueyo, J., Fujisaki, K., Galliot, B., Gao, F. B., Gewirtz, D. A., Gibson, S. B., Gohla, A., Goldberg, A. L., Gonzalez, R., González-Estévez, C., Gorski, S., Gottlieb, R. A., Häussinger, D., He, Y. W., Heidenreich, K., Hill, J. A., Høyer-Hansen, M., Hu, X., Huang, W. P., Iwasaki, A., Jäättelä, M., Jackson, W. T., Jiang, X., Jin, S., Johansen, T., Jung, J. U., Kadowaki, M., Kang, C., Kelekar, A., Kessel, D. H., Kiel, J. A., Kim, H. P., Kimchi, A., Kinsella, T. J., Kiselyov, K., Kitamoto, K., Knecht, E., Komatsu, M., Kominami, E., Kondo, S., Kovács, A. L., Kroemer, G., Kuan, C. Y., Kumar, R., Kundu, M., Landry, J., Laporte, M., Le, W., Lei, H. Y., Lenardo, M. J., Levine, B., Lieberman, A., Lim, K. L., Lin, F. C., Liou, W., Liu, L. F., Lopez-Berestein, G., López-Otín, C., Lu, B., Macleod, K. F., Malorni, W., Martinet, W., Matsuoka, K., Mautner, J., Meijer, A. J., Meléndez, A., Michels, P., Miotto, G., Mistiaen, W. P., Mizushima, N., Mograbi, B., Monastyrska, I., Moore, M. N., Moreira, P. I., Moriyasu, Y., Motyl, T., Münz, C., Murphy, L. O., Naqvi, N. I., Neufeld, T. P., Nishino, I., Nixon, R. A., Noda, T., Nürnberg, B., Ogawa, M., Oleinick, N. L., Olsen, L. J., Ozpolat, B., Paglin, S., Palmer, G. E., Papassideri, I., Parkes, M., Perlmutter, D. H., Perry, G., Piacentini, M., Pinkas-Kramarski, R., Prescott, M., Proikas-Cezanne, T., Raben, N., Rami, A., Reggiori, F., Rohrer, B., Rubinsztein, D. C., Ryan, K. M., Sadoshima, J., Sakagami, H., Sakai, Y., Sandri, M., Sasakawa, C., Sass, M., Schneider, C., Seglen, P. O., Seleverstov, O., Settleman, J., Shacka, J. J., Shapiro, I. M., Sibirny, A., Silva-Zacarin, E. C., Simon, H. U., Simone, C., Simonsen, A., Smith, M. A., SpanelBorowski, K., Srinivas, V., Steeves, M., Stenmark, H., Stromhaug, P. E., Subauste, C. S., Sugimoto, S., Sulzer, D., Suzuki, T., Swanson, M. S., Tabas, I., Takeshita, F., Talbot, N. J., Tallóczy, Z., Tanaka, K., Tanaka, K., Tanida, I., Taylor, G. S., Taylor, J. P., Terman, A., Tettamanti, G., Thompson, C. B., Thumm, M., Tolkovsky, A. M., Tooze, S. A., Truant, R., Tumanovska, L. V., Uchiyama, Y., Ueno, T., Uzcátegui, N. L., van der Klei, I., Vaquero, E. C., Vellai, T., Vogel, M. W., Wang, H. G., Webster, P., Wiley, J. W., Xi, Z., Xiao, G., Yahalom, J., Yang, J. M., Yap, G., Yin, X. M., Yoshimori, T., Yu, L., Yue, Z., Yuzaki, M., Zabirnyk, O., Zheng, X., Zhu, X., and Deter, R. L. 2008. Guidelines for the use and interpretation of assays for monitoring autophagy in higher eukaryotes. Autophagy 4:151-75.

Kuroyanagi, M., Yamada, K., Hatsugai, N., Kondo, M., Nishimura, M., and Hara-Nishimura, I. 2005. Vacuolar processing enzyme is essential for mycotoxin-induced cell death in Arabidopsis thaliana. J. Biol. Chem. 280:32914-32920.

Kwon, S. I., Cho, H. J., Kim, S. R., and Park, O. K. 2013. The Rab GTPase RabG3b positively regulates autophagy and immunityassociated hypersensitive cell death in Arabidopsis. Plant Physiol. 161:1722-1736.

Lam, E. 2005. Vacuolar proteases livening up programmed cell death. Trends Cell Biol. 15:124-127.

Laurie, J. D., Ali, S., Linning, R., Mannhaupt, G., Won, P., Güldener, U., Münsterkötter, M., Moore, R., Kahmann, R., Bakkeren, G., and Schirawski, J. 2012. Genome comparison of barley and maize smut fungi reveals targeted loss of RNA silencing components and speciesspecific presence of TEs. Plant Cell 24:1733-1745.

Liu, Y., Schiff, M., Czymmek, K., Talloczy, Z., Levine, B., and DineshKumar, S. P. 2005. Autophagy regulates programmed cell death during the plant innate immune response. Cell 121:567-577.

Lord, C. E. N., and Gunawardena, A. H. L. A. N. 2012. Programmed cell death in C. elegans, mammals and plants. Eur. J. Cell Biol. 91:603-613.

Maiuri, M. C., Zalckvar, E., Kimchi, A., and Kroemer, G. 2007. Self-eating and self-killing: Crosstalk between autophagy and apoptosis. Nat. Rev. Mol. Cell. Biol. 9:741-52.

Molina, L., and Kahmann, R. 2007. An Ustilago maydis gene involved in 
$\mathrm{H}_{2} \mathrm{O}_{2}$ detoxification is required for virulence. Plant Cell 19:2293-2309.

Nicholson, D. W., Ali, A., Thornberry, N. A., Vaillancourt, J. P., Ding, C. K., Gallant, M., Gareau, Y., Griffin, P. R., Labelle, M., Lazebnik, Y. A., Munday, N. A., Raju, S. M., Smulson, M. E., Yamin, T., Yu, V. L., and Miller, D. K. 1995. Identification and inhibition of the ICE/CED-3 protease necessary for mammalian apoptosis. Nature 376:37-43.

Pfaffl, M. W., Horgan, G. W., and Dempfle, L. 2002. Relative expression software tool (RESTC) for group-wise comparison and statistical analysis of relative expression results in real-time PCR. Nucleic Acids Res. 30:1-10.

Qiang, X., Zechmann, B., Reitz, M. U., Kogel, K. H., and Schäfer, P. 2012. The mutualistic fungus Piriformospora indica colonizes Arabidopsis roots by inducing an endoplasmic reticulum stress-triggered caspase-dependent cell death. Plant Cell 24:794-809.

Reape, T. J., Molony, E. M., and McCabe, P. F. 2008. Programmed cell death in plants: Distinguishing between different modes. J. Exp. Bot. 59:435-444

Rodríguez-Serrano, M., Bárány, I., Prem, D., Coronado, M. J., Risueño, M. C., and Testillano, P. S. 2012. NO, ROS, and cell death associated with caspase-like activity increase in stress-induced microspore embryogenesis of barley. J. Exp. Bot. 63:2007-2024.

Sanmartín, M., Jaroszewski, L., Raikhel, N. V., and Rojo, E. 2005. Caspases Regulating death since the origin of life. Plant Physiol. 137:841-847.

Sano, R., Hou, Y. C., Hedvat, M., Correa, R. G., Shu, C. W., Krajewska, M., Diaz, P. W., Tamble, C. M., Quarato, G., Gottlieb, R. A., Yamaguchi, M., Nizet, V., Dahl, R., Thomas, D. D., Tait, S. W., Green, D. R., Fisher, P. B., Matsuzawa, S., and Reed, J. C. 2012. Endoplasmic reticulum protein $\mathrm{BI}-1$ regulates $\mathrm{Ca}^{2+}$-mediated bioenergetics to promote cell death. Genes Dev. 26:1041-1054.

Shen, H. M., and Codogno, P. 2011. Autophagic cell death: Loch Ness monster or endangered species? Autophagy 7:457-465.

Thomma, B. P., Nürnberger, T., and Joosten, M. H. 2011. Of PAMPs and effectors: The blurred PTI-ETI dichotomy. Plant Cell 23:4-15.

Thornberry, N. A., Rano, T. A., Peterson, E. P., Rasper, D. M., Timkey, T., Garcia-Calvo, M., Houtzager, V. M., Nordstrom, P. A., Roy, S. Vaillancourt, J. P., Chapman, K. T., and Nicholson, D. W. 1997. A combinatorial approach defines specificities of members of the caspase family and granzyme B. Functional relationships established for key mediators of apoptosis. J. Biol. Chem. 272:17907-17911.

Uren, A. G., O'Rourke, K., Aravind, L., Pisabarro, M. T., Seshagiri, S., Koonin, E. V., and Dixit, V. M. 2000. Identification of aracaspases and Metacaspases: Two ancient families of caspase-like proteins, one of which plays a key role in MALT lymphoma. Mol. Cell 6:961-967.

van der Linde, K., Kastner, C., Kumlehn, J., Kahmann, R., and Doehlemann, G. 2011. Systemic virus-induced gene silencing allows functional characterization of maize genes during biotrophic interaction with Ustilago maydis. New Phytol. 189:471-483.

van Doorn, W. G. 2011. Classes of programmed cell death in plants, compared to those in animals. J. Exp. Bot. 62:4749-4761.

van Doorn, W. G., Beers, E. P., Dangl, J. L., Franklin-Tong, V. E., Gallois, P., Hara-Nishimura, I., Jones, A. M., Kawai-Yamada, M., Lam, E., Mundy, J., Mur, L. A., Petersen, M., Smertenko, A., Taliansky, M., Van Breusegem, F., Wolpert, T., Woltering, E., Zhivotovsky, B., and Bozhkov, P. V. 2011. Morphological classification of plant cell deaths. Cell Death Differ. 18:1241-1246.

Wang, X., Tang, C., Huang, X., Li, F., Chen, X., Zhang, G., Sun, Y., Han, D., and Kang, Z. 2012. Wheat BAX inhibitor-1 contributes to wheat resistance to Puccinia striiformis. J. Exp. Bot. 63:4571-4584.

Watanabe, N., and Lam, E. 2005. Two Arabidopsis metacaspases AtMCP1b and AtMCP2b are arginine/lysine-specific cysteine proteases and activate apoptosis-like cell death in yeast. J. Biol. Chem. 280:14691-14699.

Watanabe, N., and Lam, E. 2009. Bax Inhibitor-1, a conserved cell death suppressor, is a key molecular switch downstream from a variety of biotic and abiotic stress signals in plants. Int. J. Mol. Sci. 10:3149-3167.

Williams, B., Kabbage, M., Kim, H. J., Britt, R., and Dickman, M. B. 2011. Tipping the balance: Sclerotinia sclerotiorum secreted oxalic acid suppresses host defenses by manipulating the host redox environment. PloS Pathog. 7:e1002107. Published online.

Woltering, E. J. 2004. Death proteases come alive. Trends Plant Sci. 9:469-472.

Woltering, E. J., van der Bent, A., and Hoeberichts, F. A. 2002. Do plant caspases exist? Plant Physiol. 130:1764-1769.

Yoshimoto, K., Jikumaru, Y., Kamiya, Y., Kusano, M., Consonni, C., Panstruga, R., Ohsumi, Y., and Shirasu, K. 2009. Autophagy negatively regulates cell death by controlling NPR1-dependent salicylic acid signaling during senescence and the innate immune response in Arabidopsis. Plant Cell 21:2914-2927.

Zhang, L., Xu, Q., Xing, D., Gao, C., and Xiong, H. 2009. Real-time detection of caspase-3-like protease activation in vivo using fluorescence resonance energy transfer during plant programmed cell death induced by ultraviolet $\mathrm{C}$ overexposure. Plant Physiol. 150:1773-1783.

Zimmerman, M., Yurewicz, E., and Patel, G. 1976. A new fluorogenic substrate for chymotrypsin. Anal. Biochem. 70:258-262. 